\title{
Eocene bryozoan assemblages from the La Meseta Formation of Seymour Island, Antarctica
}

\author{
Urszula HARA ${ }^{1, *}$, Thomas MÖRS ${ }^{2}$, Jonas HAGSTRÖM² and Marcelo A. REGUERO ${ }^{3,4,5}$ \\ 1 Polish Geological Institute - National Research Institute, Rakowiecka 4, 00-975 Warszawa, Poland \\ 2 Swedish Museum of Natural History, Department of Palaeobiology, PO Box 50007, 10405 Stockholm, Sweden \\ 3 Museo de La Plata, Division Paleontologia de Vertebrados, Paseo del Bosque s/n, B1900FWA, La Plata, Argentina \\ 4 CONICET (Consejo Nacional de Investigaciones Científicas y Técnicas), Av. Rivadavia 1917 (C1033AAJ), Ciudad \\ Autonoma de Buenos Aires, Argentina \\ 5 Instituto Antarctico Argentino, Balcarce 290, (C1064AAF), Buenos Aires, Argentina
}

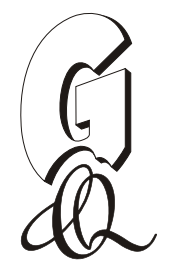

Hara, U., Mörs, T., Hagström, J., Reguero, M.A., 2018. Eocene bryozoan assemblages from the La Meseta Formation of Seymour Island, Antarctica. Geological Quarterly, 62 (3): 705-728, doi: 10.7306/gq.1432

\begin{abstract}
Early to Late Eocene bryozoans from the La Meseta Formation of Seymour Island were collected at two localities within the Cucullaea I Allomember (Telm4 and Telm5) on the northwestern side of the island and in two localities within the Submeseta Allomember (Telm6 and Telm7) on the northeastern side. This fauna is represented by cyclostomes of the suborders Tubuliporina and Cerioporina and suborders of Neocheilostomata, among which nine species have been recognized. The following new species are introduced: Micropora nordenskjoeldi sp. nov., Lunulites marambionis sp. nov., Otionellina antarctica sp. nov. and Otionellina eocenica sp. nov. Some other taxa recognized in the studied material, such as Reticrescis plicatus, Uharella seymourensis and Celleporaria mesetaensis, were previously described from the lowermost (Telm1) or uppermost parts (Telm6-7), thus their stratigraphical ranges within the La Meseta Formation are extended. The diverse growth-forms of the bryozoans include a sole ball-shaped celleporiform colony and reticulated and bilamellar-foliaceous colony, as well as rich encrusting and free-living forms (so-called sand faunas), indicating the existence of locally restricted shallow-marine environments. This is particularly true in the middle and upper parts of the La Meseta Formation (Telm4-7) Reticulated, spheroidal and robust, branched colonies, which thrived in the environmental conditions of the lower part (Telm1), are represented only by a sparse bryozoan biota in the upper part of the La Meseta Formation. Lunulitiforms, such as Lunulites and Otionellina which are warm water, free-living bryozoans, dominate in the siliciclastic sediments of Telm5 but erect folded sheets forming a shell bed composed of ? Goodonia occur in Telm6-7. These three genera are recognized in Antarctica for the first time. The austral genus Otionellina has its earliest fossil record here, showing close biogeographical links with the Late Eocene-Miocene faunas of Australia and New Zealand. The taxonomic composition of the studied fauna together with their growth forms is a very good tool for reconstructing palaeoenvironmental conditions in the middle and upper parts (Telm4-7) of the La Meseta Formation, deposited during the Late Ypresian-Priabonian.
\end{abstract}

Key words: Cyclostomata, Cheilostomata, taxonomy, Paleogene, James Ross Basin, Antarctic Peninsula.

\section{INTRODUCTION}

Seymour Island is located at the northeastern tip of the Antarctic Peninsula, where the excellent vertical and lateral exposures allow unprecedented access to Late Cretaceous-Early Paleogene marine faunas and floras at the high palaeolatitude of $65^{\circ} \mathrm{S}$ (Zinsmeister and Feldmann, 1984; Feldmann and Woodbourne, 1988; Zinsmeister, 1991; Gaździcki, 1996, 2001; Bieńkowska-Wasiluk et al., 2013).

The Eocene bryozoans from the La Meseta Formation (LMF) of Seymour Island were reported for the first time by Gaździcki

\footnotetext{
* Corresponding author, e-mail: urszula.hara@pgi.gov.pl
}

Received: March 14, 2016; accepted: May 15, 2018; first published online: November 8, 2018 and Hara (1994) and later described by Hara (1997, 1998, 2001, 2002, 2007, 2015) and Taylor et al. (2008b) in a series of systematic works. The richest bryozoan assemblage was documented from the lowermost part of the LMF (sites ZPAL 1, ZPAL 5 and ZPAL 11-12) exposing a 2 metre thick basal layer of Telm1 in the northwestern part of the island (Hara, 2001). The bryozoan fauna here comprises 43 species of the dominant cerioporine cyclostomes along with cheilostomes belonging to microporoideans, and umbonulomorph and lepraliomorph ascophorans, where the majority of colonies show multilamellar growth. The strata are composed of poorly consolidated sandstones and siltstones, which represent the lowermost part of the LMF (Telm1, see Sadler, 1988) or the Valle de las Focas Allomember sensu Marenssi et al. (1998), and they are interpreted to be of Early Eocene age (52-54 Ma; see López-Cabrera and Olivero, 2011).

Three studies of the Early-Middle Eocene bryofauna from the LMF give a combined total of 45 species to date (Hara, 
2001, 2002; Taylor et al., 2008b). Some new records of bryozoan internal moulds from the lowermost part of this formation have been added more recently (Hara, 2015). Other Southern Hemisphere Early Eocene bryozoans, which pre-date the La Meseta bryofauna, were described from Chatham Island, New Zealand. These very speciose and taxonomically diverse faunas consist of a total of 119 species, of which 62 were new to science, many representing the oldest fossil records of particular taxa (Gordon and Taylor, 1999, 2015). Investigations of the basal facies of the South Maslin Sands of the Middle to Late Eocene Tortachilla Limestones of the St. Vincent Basin, South Australia, have revealed the presence of $>250$ species (Schmidt and Bone, 2001, 2003), among which the free-living lunulitiform bryozoan Otionellina cf. exigua occurs in relatively unconsolidated sediments containing goethite pellets, probably deposited within the wave base zone (Schmidt, 2007). Taxonomic research on Southern Hemisphere Eocene bryozoans has been sparse, but the early twenty-first century has seen an increase in taxonomic studies (Gordon and Taylor, 2015). The earlier taxonomic studies from the Late Eocene of the Otway Basin by Maplestone (1904), and other taxonomic and phylogenetic work of Gordon and Braga (1994) together with records from the Eocene of the LMF (Hara, 2001, 2002), may potentially be used to evaluate the biogeography of the Austral Eocene bryozoans in relation to palaeolatitude and circulation (Gordon and Taylor, 2015).

The bryofauna from the middle and upper part of the LMF (Late Ypresian-Priabonian), which is the focus of the current paper, was collected from shallow-water marine horizons of the Cucullaea I Allomember (Telm4-5, Ypresian) and from the Submeseta Allomember (Telm6-7, Lutetian and Bartonian/Priabonian) during three Argentine-Swedish Antarctic campaigns (2011-2013). The main objective of the paper is to describe the nine species from the LMF. These include two cyclostomes, represented by the tubuliporid ?/dmidronea sp. and the cerioporine Reticrescis plicatus, together with seven cheilostomes belonging to the Neocheilostomatina, i.e. the microporoideans, Micropora nordenskjoeldi sp. nov., Lunulites marambionis sp. nov., Otionellina antarctica sp. nov. and Otionellina eocenica sp. nov., and the lepraliomorphs, Celleporaria mesetaensis and as well as the brydonellid umbonulomorph Uharella seymourensis and another adeonellid umbonulomorph represented by the incertae sedis genus Goodonia described here as ?Goodonia sp. This fauna adds a valuable new record of bryozoans from the middle part of the LMF (Telm4-5), which have never been described from Antarctica, as well as those which were formerly described from the lower or uppermost parts of the LMF (Telm1, 6-7). It also extends the stratigraphical occurrence of some taxa, which previously were recognized either from the lower or upper parts of the LMF. The Antarctic La Meseta bryofauna helps to fill a gap in the knowledge of the Southern Hemisphere bryozoans, particularly because it adds either the earliest occurrences or first fossil records from this continent.

Mineralogically, the bryozoan skeletons from the middle part of the La Meseta Formation (Telm4-5) are formed of intermediate-Mg calcite (IMC). The initial examination using XRD-diffraction has proved the presence of the traces of aragonite and strontium apatite. The scarcity of the bryozoan material, however, considerably limited the expectation of receiving better results.

\section{GEOLOGICAL SETTING}

The Lower to Upper Eocene/?lowermost Oligocene LMF is exposed on Seymour and Cockburn islands in the Weddell Sea. It represents the only exposed succession of this age in Antarctica (Elliot and Trautman, 1982; Ivany et al., 2006, 2008). The LMF is part of the sediment fill of the James Ross Basin, a back-arc basin developed on the eastern flank of the Antarctic Peninsula (Elliot, 1988; Del Valle et al., 1992; Hathway, 2000; cf. Mozer, 2013). Resting unconformably on either the Upper Cretaceous López de Bertodano Formation or the Paleocene Sobral and Cross Valley formations, the LMF is interpreted as the filling of a $7 \mathrm{~km}$ wide incised-valley system (Sadler, 1988; Marenssi et al., 1998, 2002; Marenssi, 2006). The unit consists of unconsolidated sandstones and mudstones with intercalated coquina conglomerates of $\sim 720 \mathrm{~m}$ in composite thickness. Marenssi et al. (1998) proposed six erosionally based internal units: Valle de Las Focas (= Telm1), Acantilados (= Telm2-3), Campamento $(=$ Telm3), Cucullaea I (= Telm4-5), Cucullaea II $(=$ Telm5) and Submeseta $(=$ Telm6-7) Allomembers. These unconformable allomembers were deposited in deltaic, estuarine and shallow marine settings (Marenssi et al., 1998, 2002; Marenssi, 2006; Tatur et al., 2011).

The basal part of the approximately $80 \mathrm{~m}$ thick Cucullaea I Allomember is an up to $3 \mathrm{~m}$ thick shell bed (unit Telm4 of Sadler, 1988) dominated by the large thick-shelled bivalve Cucullaea raea and darwinellid gastropods, but also containing abundant vertebrate remains, especially shark teeth (Reguero et al., 2012). This Cucullaea I shell bed is overlain by a series of purple and grey-green fine-grained sands and silty clays intercalated with shell lenses (Telm5). Sedimentological features of the Cucullaea I Allomember are parallel laminations, flaser and wavy bedding as well as ripples, small channels and burrows (Elliot and Trautman, 1982; Sadler, 1988; Stilwell and Zinsmeister, 1992). The shell lenses are dominated by Cucullaea, but one horizon is dominated by the gastropod Polynices. The up to $1 \mathrm{~m}$ thick lenses of the "Natica Horizon" pinch out laterally within a few metres, but they are exposed at several places along the western flank of the meseta. The Cucullaea I Allomember is unconformably overlain by another thick Cucullaea shell bed, representing the lowermost part of the Cucullaea II Allomember (also Telm5).

The depositional environment of the Cucullaea I Allomember can be interpreted as a nearshore, high-energy environment (Stilwell and Zinsmeister, 1992). The fossil content of the Cucullaea I Allomember is largely restricted to conglomeratic shell beds and lenses. The fauna is dominated by the large thick-shelled bivalve, Cucullaea raea, and the thick-shelled gastropods, Antarctodarwinella nordenskjoldi and Struthiolarella steinmanni. These are associated with other marine molluscs, brachiopods, crinoids, starfish, asteroids, sea urchins, nautiloids and crabs, as well as the trace fossils Diplocraterion, Scoyenia, Skolithos and Ophiomorpha (Stilwell and Zinsmeister, 1992; Cione and Reguero, 1998; Tatur et al., 2011). Marine vertebrates are also very abundant, especially sharks, skates, rays and chimaeras. The selachian fauna is more diverse than most of extant temperate faunas and almost equal to present-day tropical faunas (Kriwet and Gaździcki, 2003; Reguero et al., 2013). Additionally, remains of marine teleosts, basilosaurid whales, marine turtles, and penguins can 


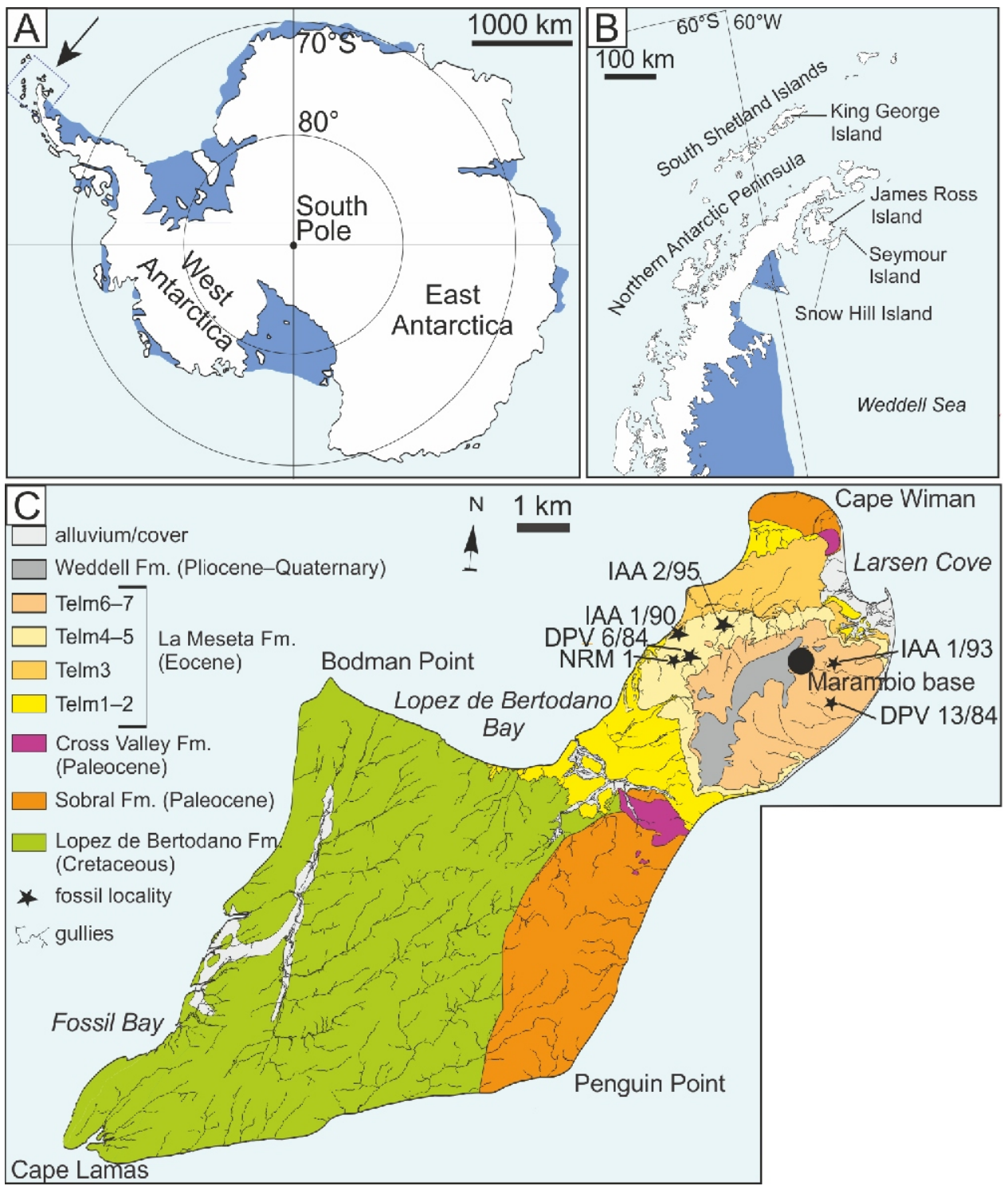

Fig. 1. Location map

A - map of Antarctica showing the position of the Antarctic Peninsula; B - map of the Antarctic Peninsula showing Seymour Island; $\mathbf{C}$ - geological map of Seymour Island showing the outcrops of Telm4-7 and localities NRM 1, IAA 1/90, IAA 2/95, IAA 1/93, DPV 13/84 and DPV 6/84

be found (Buono et al., 2016; Schwarzhans et al., 2016). The Cucullaea I Allomember contains also some terrestrial elements, i.e. fossil wood, which is heavily bored by teredinid bivalves, cocoons of clitellates, and a range of terrestrial mammals (Bomfleur et al., 2015; Gelfo et al., 2015, McLoughlin et al., 2016).

Most bryozoans described here come from two Telm5 "Natica Horizon" localities, IAA $1 / 90$ and IAA 2/95 (Figs. 1-3A-D). They are dominated by microporoideans belonging to the families Lunulitidae, Otionellidae and Microporidae. One specimen of the cyclostome Reticrescis also occurs. A representative of the family Brydonellidae - Uharella seymourensis - which is also documented from IAA 2/95 (Telm5), is present in the Telm4 locality NRM 1 (Cucullaea shell bed, GPS data: $64^{\circ} 14.284^{\prime} S 056^{\circ} 40.182^{\prime} \mathrm{W}$, Fig. 3E) and in the Telm6 locality IAA 1/93 (Submeseta, GPS data: 64⒈'25"S; 56 35'51"W). IAA 1/90 (GPS data: 64¹4'04.67"S; $56^{\circ} 39^{\prime} 56.38^{\prime \prime} \mathrm{W}$, Figs. $\left.1-3 \mathrm{~A}, \mathrm{~B}\right)$, also known as the "Ungulate Site" (Marenssi et al., 1998), a conglomeratic lens almost $1 \mathrm{~m}$ thick. The sediment matrix is composed of fine to coarse sand with many bioclasts (mainly naticids) and pebbles up to $20 \mathrm{~cm}$ in size. IAA 1/90 is situated within the Struthiolarella steinmanni Zone of Stilwell and Zinsmeister (1992). IAA 2/95 (GPS data: $64^{\circ} 13^{\prime} 58^{\prime \prime}$; $56^{\circ} 39^{\prime} 06^{\prime \prime W}$, Figs. 1-3C, D), known as the "Marsupial Site", is also a conglomeratic lens with lithology comparable to IAA $1 / 90$, but thinner.

\section{MATERIAL AND METHODS}

The studied bryozoans were found in the residuum of already sieved and sorted bulk sediment samples, except for NRM-PZ By 141128-141131 from Telm7, which is a surface sample. The material was collected when prospecting for terrestrial vertebrates in the LMF on Seymour Island during the austral summers of 2011-2013 (Fig. 3), organized by the Argentine Antarctic Institute (IAA-DNA) in collaboration with the Swedish Polar Research Secretariat (SPFS). 


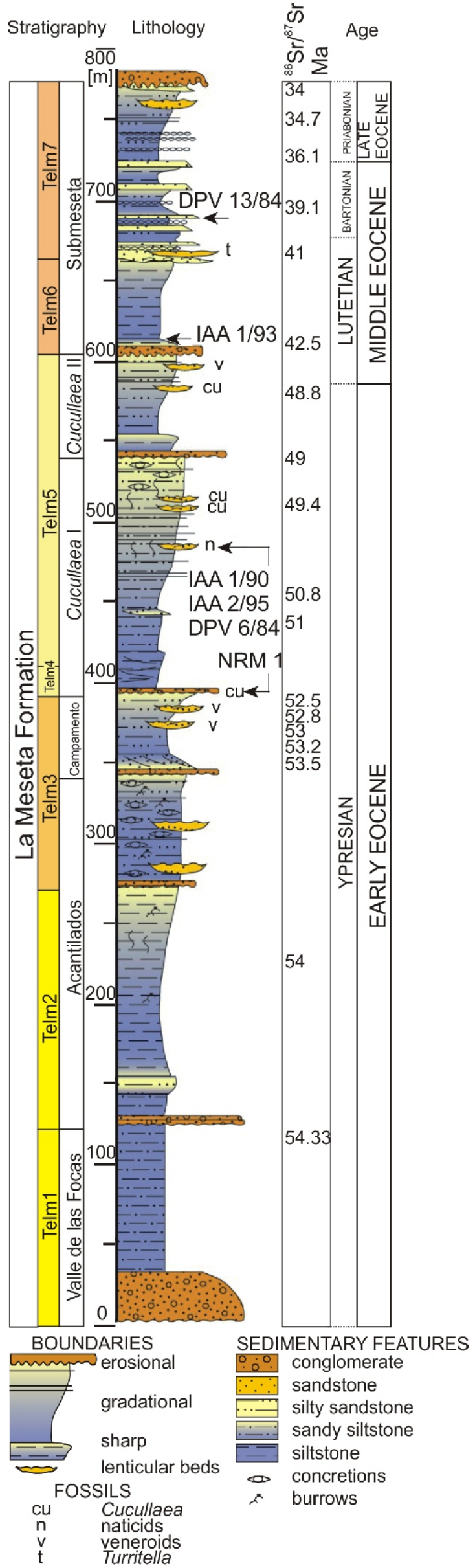

Over 130 fragments of bryozoan colonies were used for the taxonomic study. They derive from unconsolidated clastic sediments from one Telm4 locality, NRM 1; two Telm5 localities, IAA 1/90 (also known as the Ungulate Site), and IAA 2/95 (known as the Marsupial Site), and one Telm4-5 locality DPV 6/84 (called Rocket Site), as well as one Telm6 locality IAA 1/93 (see Fig. 1C). In addition, rather poorly preserved large individual reticulate or ball-shaped cyclostome and cheilostome bryozoan colonies were collected from the upper part of the LMF (DPV 13/84, Telm7, Fig. 3F) in the northeastern part of the island (Fig. 1). The majority of the studied material is composed of small, fragile fragments of colonies, which derive from the residues of sieved bulk samples. The residues were sieved through mesh sizes from 4.0 to $0.5 \mathrm{~mm}$, and in part of $0.063 \mathrm{~mm}$. Bryozoans were absent in the finest fraction. Ultrasonic cleaning was employed to remove weakly adherent matrix. All described taxa were examined and measured using a WILD M10 binocular microscope. Well-preserved specimens were studied with scanning electron microscopes at the Polish Geological Institute - National Research Institute (Warsaw), a ZEISS-LEO 1430 SEM, and a SIGMA VP ZEISS SEM (Environmental Laboratory of Low Temperature Scanning Electron Microscopy) at the Department of Geology (University of Warsaw). X-ray diffraction (XRD) was performed at the Chemical Laboratory of the Polish Geological Institute - National Research Institute using an X. Pert PW 3020 Philips for seven samples, among which four specimens belonged to Otionellina antarctica from two localities (IAA 2/95 and AAI/90) and three fragments of colonies of Lunulites marambionis sp. nov. from locality IAA 2/95. Minimal quantities of ground material were used for the XRD analyses; therefore, the samples were prepared on glass. The diffractograms may be disrupted by the changed intensity relationships and angular shifts of the reflection. The chemical composition of the selected specimens from the middle and upper part of the La Meseta Formation as well as the average mole $\% \mathrm{MgCO}_{3}$ content were analysed using the electron microprobe Cameca SX-100 at the Micro-area Analysis Laboratory at the Polish Geological Institute - National Research Institute.

The illustrated material (Figs. 4-10) is based on 34 selected specimens presented as back-scattered electron micrographs. Material illustrated in Figure 10 was gold-coated before imaging. A few thin sections have been made from the studied material at the Academy of Metallurgy (Cracow). The studied material is catalogued as NRM-PZ By 24207-24215 and NRM-PZ By 141128-141134, and the holotypes are marked by the suffix " $h$ ". The collection is housed in the palaeozoological collections of the Swedish Museum of Natural History, Department of Palaeobiology in Stockholm. Two comparative specimens, illustrated in Figures $4 \mathrm{~L}$ and $9 \mathrm{~F}$, are deposited at the Institute of Paleobiology of the Polish Academy of Sciences, Warsaw (Poland) under the catalogue number ZPAL Br. VIII/A.

Fig. 2. Composite stratigraphical section (from Reguero et al., 2013) through the La Meseta Formation showing the stratigraphic position of the samples

Strontium date values from Dingle and Lavelle (1998); Dutton et al. (2002); Ivany et al. (2008) and Reguero et al. (2012) 

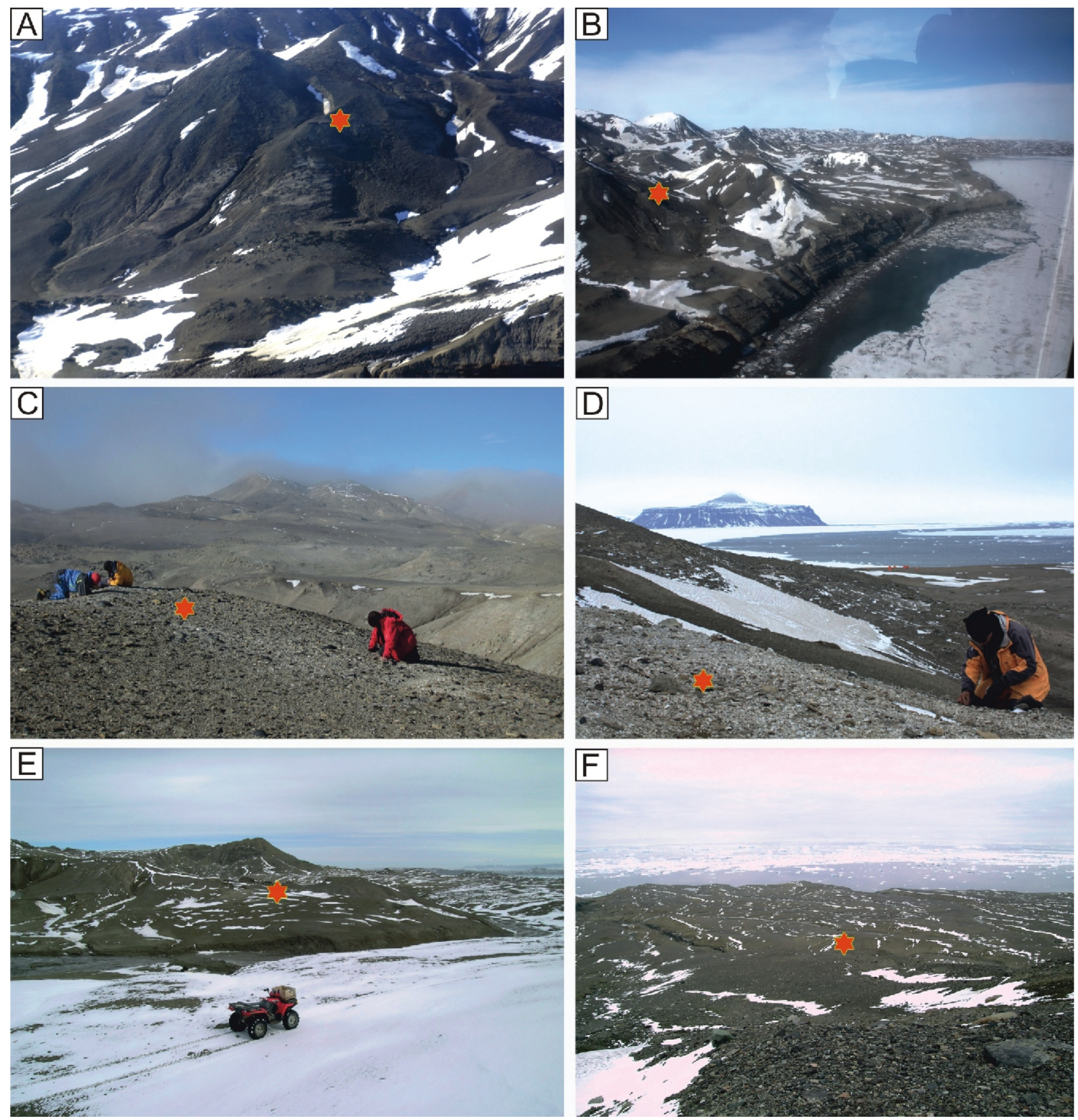

Fig. 3A-F - location photographs

A, B - aerial views of Telm5 locality IAA 1/90, "Ungulate Site", marked by asterisk; C, D - Argentine-Swedish field party collecting fossils at Telm5 locality IAA 2/95, "Marsupial Site", marked by asterisk; E - Telm4 locality NRM 1, marked by asterisk; F - Telm7 locality DPV 13/84, marked by asterisk; photographs by T. Mörs (A, E, F); F. Degrange (B, D) and J. Hagström (C)

\section{SYSTEMATICS}

Order Cyclostomata Busk, 1852

Suborder Tubuliporina Milne-Edwards, 1838

Family Tubuliporidae Johnston, 1838

Genus Idmidronea Canu et Bassler, 1920

Type species: Idmonea cornopus Defrance, 1822 ?ldmidronea sp.

(Fig. 4A-J)
M a t e r i a I. - 1 complete zoarium, NRM-PZ By 141131.

D i m e $\mathrm{n}$ s i o n s. - Colony height $11 \mathrm{~mm}$, width $15 \mathrm{~mm}$. Width of the supporting base $5.5 \times 6.0 \mathrm{~mm}$. Diameter of the primary stem close to the expanded base $3.7 \mathrm{~mm}$. Thickness of the branch close to the supporting base $2.0-2.25 \mathrm{~mm}$. Lateral branch diameter in the middle part of the colony 1.1-1.45 $\mathrm{mm}$. Diameter of the branch close to the top of the colony $0.62-0.75 \mathrm{~mm}$. Apertural length $0.12-0.20 \mathrm{~mm}$, width $0.08-0.12 \mathrm{~mm}$. Distance between the zooecial rows $0.24-0.32 \mathrm{~mm}$. Peristome length $0.20-0.25 \mathrm{~mm}$, width $0.16-0.26 \mathrm{~mm}$. Kenozooecium length $0.20 \mathrm{~mm}$, width $0.08 \mathrm{~mm}$. Width of the exozone $0.16-0.32 \mathrm{~mm}$. Width of the 

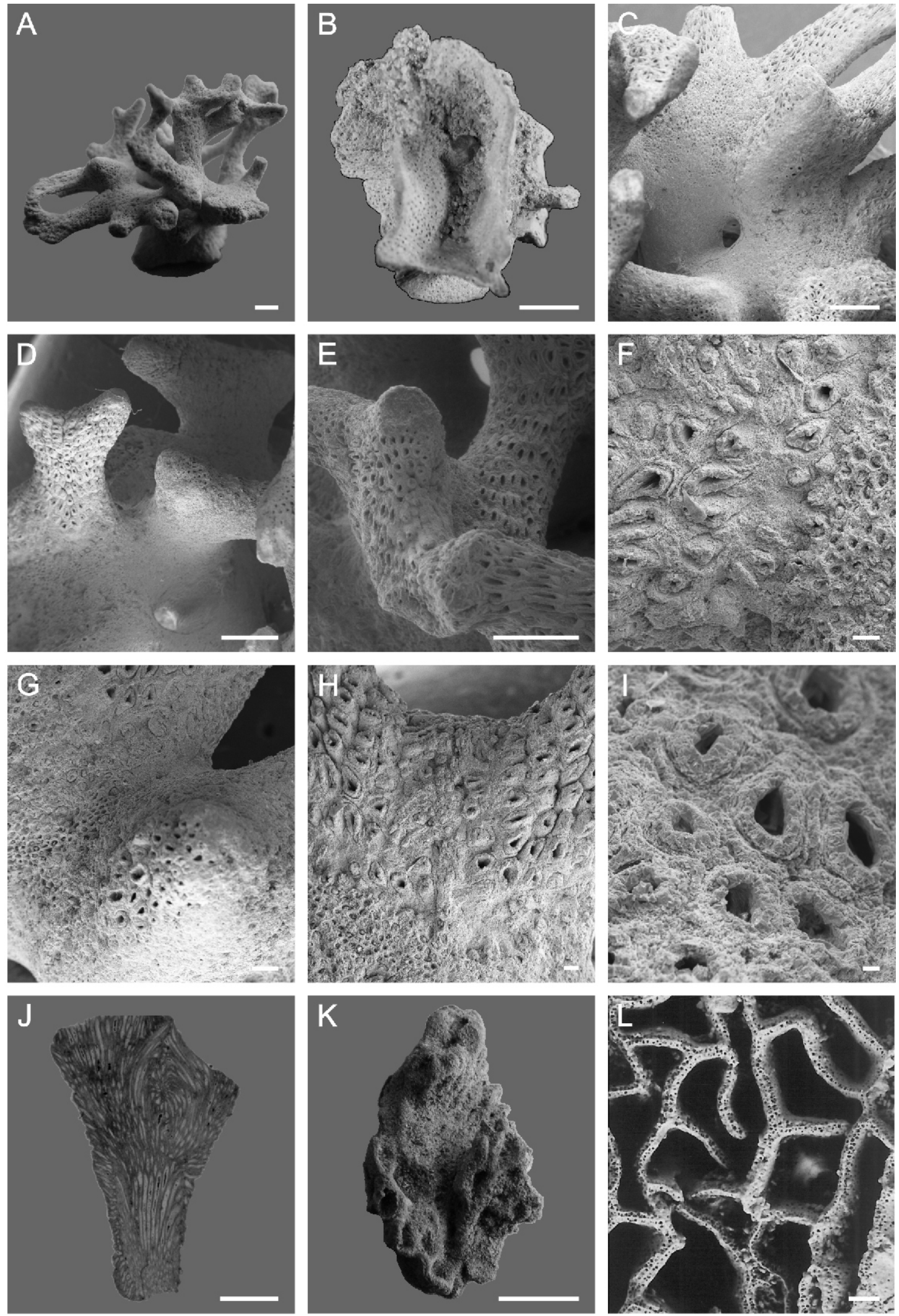

Fig. 4A-J - Idmidronea sp. (specimen By 141131, Telm7); K, L - Reticrescis plicatus Hara, 2001: K - specimen By 24208, locality IAA 1/90, Telm5, L - ZPAL Br. VIII/A42, ZPAL 1, Telm1, K, L - La Meseta Formation, Seymour Island, James Ross Basin, Antarctic Peninsula, Eocene

A - side view of the dendroid colony, scale bar $1.35 \mathrm{~mm}$; $\mathbf{B}$ - back side of the proximal part of the colony showing the supporting disc with marked layering, scale bar $3 \mathrm{~mm} ; \mathbf{C}$ - general upper view of the colony, scale bar $1 \mathrm{~mm}$; D - view of the distal part of the colony with dichotomously branching stems, scale bar $200 \mu \mathrm{m}$; E - branches showing the arrangement of autozooecia, scale bar $1 \mathrm{~mm}$; $\mathbf{F}-$ area without apertures (on the left), and with apertures (on the right), scale bar $100 \mu \mathrm{m} ; \mathbf{G}$ - area without apertures at the bifurcation of the branches, scale bar $200 \mu \mathrm{m} ; \mathbf{H}$ - close-up of the area at the bifurcation of two branches, showing the place without apertures in the middle, scale bar $100 \mu \mathrm{m} ; \mathbf{I}-$ apertures with a distinct rim ranging in shape from oval to triangular, scale bar $20 \mu \mathrm{m}$; $\mathbf{J}$ - longitudinal section through a lateral branch, showing the zooecial walls in the exozone and endozone, scale bar $0.5 \mathrm{~mm} ; \mathrm{K}$ - fragment of reticulate colony from a dorsal view, scale bar $9 \mathrm{~mm}$; $\mathrm{L}$ - fenestre of the branches from the frontal view showing the budding laminae, scale bar $0.25 \mathrm{~mm}$ 
endozone $0.4-0.64 \mathrm{~mm}$. Longitudinally sectioned interzooidal walls ca. $0.025-0.05 \mathrm{~mm}$ thick.

Description. - Colony erect, stout, dendroid, strongly calcified, consisting of two thick main branches, which arise roughly perpendicularly from the marginal part of the triangular supporting base (Fig. 4A, B). The secondary stems bifurcate, up to the top of the colony, giving rise to the smaller bifurcating branches tapering towards the distal branch tips (Fig. 4A D). Lateral branches in the distal part of the colony are of a different length; some are very short, some longer, and they grow either in a distal or horizontal direction forming an irregular tree-like colony (Fig. 4A). Some branches are diverging; they also rarely anastomose. In the cross-section, branches are subcylindrical to cylindrical (Fig. 4C, E) but may be roughly blade-shaped at the top of the colony (Fig. 4A, D). The supported proximal base expanding in diameter, is overgrown by a system of kenozooecia and composed of several distinct, superimposed growing layers seen on the concave underside of the colony (Fig. 4B). Autozooecia are arranged in transverse fascicles; each half series consisting of five autozooecia parted in the middle, without mid-line keel, forming closely $\mathrm{V}$-shaped linear series on the frontal wall (Fig. 4D, E). Some zooecia are closed by the diaphragms, but more often the diaphragms are not seen (Fig. 4E, H). Apertures oval to roughly triangular close to each other, surrounded by peristomes that protrude slightly above the zoarial surface; they are mostly connate (Fig. 4E, F, $\mathrm{H}, \mathrm{I})$. Most of the apertures are on the same level on the whole zoarial surface, however, some are protruberant (Fig. 4I) Newly budded raised areas, resembling short branches and composed of closely spaced apertures, are seen on the zoarial surface (Fig. 4G). The colony surface is covered by irregularly distributed small areas filled by roughly rounded, equidimensional minute pores, $0.025-0.04 \mathrm{~mm}$ in diameter, which particularly occur slightly below the bifurcation on the frontal wall (see Fig. 4G, H). These areas may be associated with the secondary thickening layer. The reverse side of the zoarium is slightly convex; at the base in the proximal part, the supporting disc is composed of numerous kenozooecia, which seem to be smaller in the distal part of the zoarium. The limits between kenozooecia are marked by the slightly elevated lines or ridges running almost parallel to the extremities of the branches. In some parts of the zoarium the lines are very distinct (see partly Fig. 4C). The whole reverse side is corroded, in places uneven, showing some empty spaces when the kenozooecia are missing or worn. Gonozooecium are not present. The internal structure, which is seen in the longitudinal section, shows long autozooecia with apparent kenozooecia on the left of the thin-section, which might be the dorsal kenozooecia. The boundary between the exozone and endozone is well-defined (Fig. 4J). The endozone occupies about three-quarters of the branch diameter and is surrounded by a very thin exozone (Fig. 4J). The zooecial walls are of varied thickness and laminated in the exozone, whereas in the endozone they rarely possess interzooecial pores.

$\mathrm{R} \mathrm{e} \mathrm{marks.} \mathrm{-} \mathrm{The} \mathrm{specimen} \mathrm{studied} \mathrm{and} \mathrm{illustrated} \mathrm{in}$ Figure 4A-J is tentatively assigned to ?/dmidronea sp. It shows a similar pattern of colony branching to Idmidronea rosacea Canu and Bassler, 1920, which is supported by the expanded base. The branches are directed mostly in the upper part either vertically or horizontally, in all directions. They are diverging and anastomose, occasionally forming a rotate, bush-like, dendroid colony form (see Canu and Bassler, 1920: 784, 786-78 E). The width of the branches towards the supporting base is comparable between I. rosacea $-2.0 \mathrm{~mm}$ versus $2.0-2.25 \mathrm{~mm}$ in the studied specimen.
The characteristic feature of the Idmidronea species is the arrangement of the autozooecia, originating along or near one side of the branch, and apertures opening on the other two sides, which constitute the frontal side of the branch (see Taylor and McKinney, 2006). The specimen studied shows the autozooecia on the frontal wall disposed in a characteristic linear pattern, in five from each side (see Fig. 4D, E), forming the fascicles, whereas kenozooecia on the reverse side are arranged close to each other, occupying the whole zoarial surface and showing almost the same size in the length and width as the autozooecia. In some places, they are corroded, leaving the empty spaces that resemble large pores, scattered evenly. The longitudinal lines between the kenozooecia are well-seen. Branches of another idmidroneiform genus - Pleuronea Canu and Bassler, 1920 have kenozooecia disposed similarly on the whole reverse side as the specimen studied, contrary to Idmidronea colonies, in which polymorphs are lacking in the most distal parts of the reverse side (Taylor and McKinney, 2006; see also Hinds, 1975: 887, text-fig. 10).

The dorsal kenozooids of the specimen are seen in the thin-section illustrated in Figure 4J, on the left (see also Canu and Bassler, 1920: 642, fig. 203; Małecki, 1963: 68, fig. 28). The arcute growth layers, which are free of kenozooids (firmatopores) and usually found on the distal part of the Idmidronea branches, have not been seen in the examined specimen. Its reverse side is similar to Pleuronea, showing the large polygonal tergopore-like kenozooids - see also Małecki (1963: table III, fig. 5a). The majority of species assigned to Idmidronea often show a triangular rather than a circular to oval branch section, such as in the specimen studied; however, this may depend on the age of the colony (see also Ostrovsky and Taylor, 1996: p. 1557). The characteristic feature of the specimen studied, which does not occur in Idmidronea, is the presence of irregularly-shaped mesh-like areas covered by roughly polygonal to circular, equidimensional small pores (?kenozooecia or ?cancelli) located below the bifurcation of the branches (see Fig. 4F-H), that may also be associated with the process of secondary calcification of the frontal wall. The recent species of Calvetia osheai, described from northernmost New Zealand (Taylor and Gordon, 2003), shows distinct zones of cancelli; its supporting base is of the same size as the specimen studied, and the two taxa show similar dimensions of the lateral branches $(1.1 \mathrm{~mm}$ in C. osheai versus $0.8-1.2 \mathrm{~mm}$ in the specimen). However, Calvetia has free-walled autozooecia with calcified frontal walls. The raised areas (Fig. 4G) with closely spaced apertures, often clustered, resembles the short branches of $I$. osheai (see Taylor and Gordon, 2003: 664, fig. 7A; Fig. $4 \mathrm{G}$ in this paper). On the other hand, the arrangement of the autozooecia and kenozooecia is the most important character in discriminating genera and families, and the studied specimen show a distinct Idmidronea-like pattern, mostly on the frontal wall. Idmidronea antarctica, described from Antarctic (Borg, 1944; Ostrovsky and Taylor, 1996), shows similarity in the number of autozooecia in fascicles, which can vary from 2-6 or 3-5, but also often occur in 5, in the shape and size of the apertures. However, it differs in the distance between the fascicles, which is longer, and generally in the appearance of the dorsal wall.

No gonozooids are present both in the only available specimen and in the very sparse material available from Seymour Island (Telm7), making the assignment to Idmidronea uncertain.

O c c u r r e n c e. - DPV 13/84, Submeseta Allomember (Telm7), La Meseta Formation, Seymour Island, James Ross Island, Eocene. 
Suborder Cerioporina Waters, 1887

Family Cerioporidae Waters, 1880

Genus Reticrescis Hara, 2001

Type species: Reticrescis plicatus Hara, 2001

Reticrescis plicatus Hara, 2001

(Fig. 4K, L)

1997a. Reticrescis Hara: fig. 2g, fig. 3:7.

19997b. Reticrescis patagonica (Ortmann, 1900); Hara: 120, 126, fig. 4: 19: fig. 5C.

2001. Reticrescis plicatus Hara: 60-62, Pls 1: 7; 9: 1a-c; 2, 3a, b, 4a-b; 10: 1a-d, 2, 3, Text-fig. 21.

M a te ri a I. - Fragment of reticulate zoarium (in two parts), NRM-PZ By 24208.

D i m e n s i on s. - Length of the fragment of zoarium (max.) $27 \mathrm{~mm}$, width $11 \mathrm{~mm}$; thickness of the branch 0.5-0.6 mm, width of the branch 3.4-4.2 $\mathrm{mm}$; length of fenestra of reticulation $2.4-6.7 \mathrm{~mm}$, width of fenestra 0.8-1.82 $\mathrm{mm}$; frontal wall length (of autozooecia) $0.22-0.25 \mathrm{~mm}$; apertural width $0.08-0.11 \mathrm{~mm}$; peristome length $0.28-0.30 \mathrm{~mm}$; kenozooecial diameter $0.02 \mathrm{~mm}$.

$\mathrm{D}$ e s c r i p t i o n. - Zoarium reticulate, erect, consisting of compressed branches, with horizontal radial growth dominant in the lower part of the colony. Vertical growth present in the upper part (Fig. 4L). The zoarial surface is worn. The branches of the colony show a bilamellar structure (Fig. 4L), and all bifurcate in the same plane. The dorsal side of zoarium is covered by large pores, but longitudinal ridges are not seen. The zoarium (Fig. 4K) is covered by a slightly projecting oval-shaped autozooecia, arranged in quincunx and encircled by slightly oblique, thick peristomes. Sunken, small apertures are barely seen, which may represent polymorphs. Possibly kenozooecia are distributed unevenly on the lateral branches (Fig. 4K). The frequency of kenozooecia, as well as their acute projections (pseudolunaria), is not clear due to the state of preservation of the specimens. The bilamellar nature of the branches with well-marked median ridge corresponding to the budding lamina is seen on the frontal side of the branch (Fig. 4L). A brood chamber is not found.

$\mathrm{R}$ e $\mathrm{m}$ a r k s. - The rich and excellently preserved bryozoans from the lower part of the La Meseta Formation include Reticrescis plicatus Hara, 2001, described from localities ZPAL 1 and ZPAL 12 of (Telm1) along with poorly preserved specimens from the upper part of the LMF at ZPAL 3 of Telm7 (Hara, 2001: 61-62, Pls 1: 7; 9: 1a-c: 2, 3a, b, 4a, b: 10: 1a-d, 2). The material studied here from Telm5 of the LMF shows all the morphometric and morphologic features corresponding to the specimens described by Hara (2001; Fig. 4L). Brood chambers are not present in the new material. The very characteristic feature of $R$. plicatus Hara, 2001, is the reticulate form of the colony. It consists of compressed branches with horizontal growth dominant in the lower part of the colony and vertical growth in the upper part (Fig. 4K, L; cf. Hara, 2001: Pls 9: 1a-c, 2, 3a, b, 4a, b: 10: 1ad, 2). The zoarial form of $R$. plicatus is similar to those of Reticulipora patagonica Ortmann, 1902 and $R$. transennata Waters, 1884, but the morphology and the pattern of arrangement of autozooecia and kenozooecia on the colony surface are different in these species from the Miocene of Patagonia and the Eocene of Aldinga, South Australia, respectively (Waters, 1884: pl. 30: 3; see also Hara, 2001: 62). The preservational state of $R$. plicatus in the lower part of the LMF is different than in the upper part. The previously studied material from Telm7 and that examined here from Telm5 is poorly preserved (cf. Hara, 2001: text-fig. 21; Fig. 4K).
O c c u r r e n c e. - IAA 1/90 (Ungulate Site), Natica Horizon, Cucullaea I Allomember (Telm5), La Meseta Formation, Seymour Island, James Ross Island; Eocene.

Order Cheilostomata Busk, 1852

Suborder Neocheilostomatina d'Hondt, 1985

Superfamily Microporoidea Gray, 1848

Family Microporidae Gray, 1848

Genus Micropora Gray, 1848

Type species. Flustra coriacea Johnston, 1847, Recent, NE Atlantic

Micropora nordenskjoeldi sp. nov. (Fig. 5)

Holotype: Specimen NRM-PZ By 24211h, illustrated in Figure 5A-F.

Type horizon: Natica Horizon, Cucullaea I Allomember (Telm5), La Meseta Formation, Eocene.

Type locality: IAA 1/90 (Ungulate Site), Seymour Island, James Ross Basin, Antarctic Peninsula.

Derivation of the name: In honour of the explorer and geologist Dr Otto Nordenskjöld, who led the Swedish South Polar Expedition (1901-1903).

M a te ri a I. - One colony encrusting a fragment of a serpulid worm, NRM-PZ By $24211 \mathrm{~h}$.

$\mathrm{M}$ e a s u re me nt s. - Length of the colony $6.3 \mathrm{~mm}$; length of zooecium $0.44-0.56 \mathrm{~mm}$, width of zooecium $0.17-0.46 \mathrm{~mm}$; length of opesium $0.07-0.09 \mathrm{~mm}$, width of opesium $0.11-0.16 \mathrm{~mm}$; length of ovicell $0.19-0.25 \mathrm{~mm}$, width of ovicell $0.17-0.21 \mathrm{~mm}$; length of avicularium $0.14-0.18 \mathrm{~mm}$, width of avicularium $0.10-0.12 \mathrm{~mm}$.

D e s c ription. - Colony small, encrusting a serpulid worm. Autozooecia irregular in shape, more or less hexagonal to strongly elongate; width half of the length; separated by a narrow distinct interzooecial furrows (Fig. 5A-D). In some places they are crowded, and often differently oriented (Fig. 5C). Lateral walls of autozooecia raised (Fig. 5A, D). Cryptocyst slightly convex, finely granular, with $25-40$ rounded, rather large pores (Fig. 5A-D). In some zooecia, the pores are scarce and show patchy distribution, which may suggest that the occurrence of the epitaxial cement on the cryptocyst may account for the lack of visible pores in some of the zooids (Fig. 5A, D). A pair of deeply recessed opesiules, elongated in shape and $0.07-0.08 \mathrm{~mm}$ long, is placed proximally to the orifice-opesiae; each with a single pore, $0.03 \mathrm{~mm}$ in diameter, just proximal to it (Fig. 5B, C). Opesiae semicircular to slit-like, placed at the extremity of the autozooecium, nearly twice as wide as long. Proximal edge straight and raised (Fig. 5A-E). The border of the opesiae well-marked, surrounded by a distinctive, narrow rim of smooth calcification (Fig. 5A-D). No oral spines. Avicularia interzooecial, sparsely distributed, placed distally of opesia when present, or sometimes close to the proximal margin of zooecia; oval-shaped, directed distolaterally, and show a slightly smaller length than the width of opesia. Rostrum triangular, gently acute, highly raised upward above the surface of the zoarium. A very thin cross-bar, placed medially (Fig. 5C, D). Ovicell hyperstomial, imperforate but mildly granular, convex, slightly longer than wide, bordered proximally by a rather board smooth rim (Fig. 5E, F), 0.04-0.07 mm wide, with a low knob placed in the middle of the rim (Fig. 5E, F). One of the ovicells shows a narrow tube running through the middle of the rim (see Fig. 5E). 

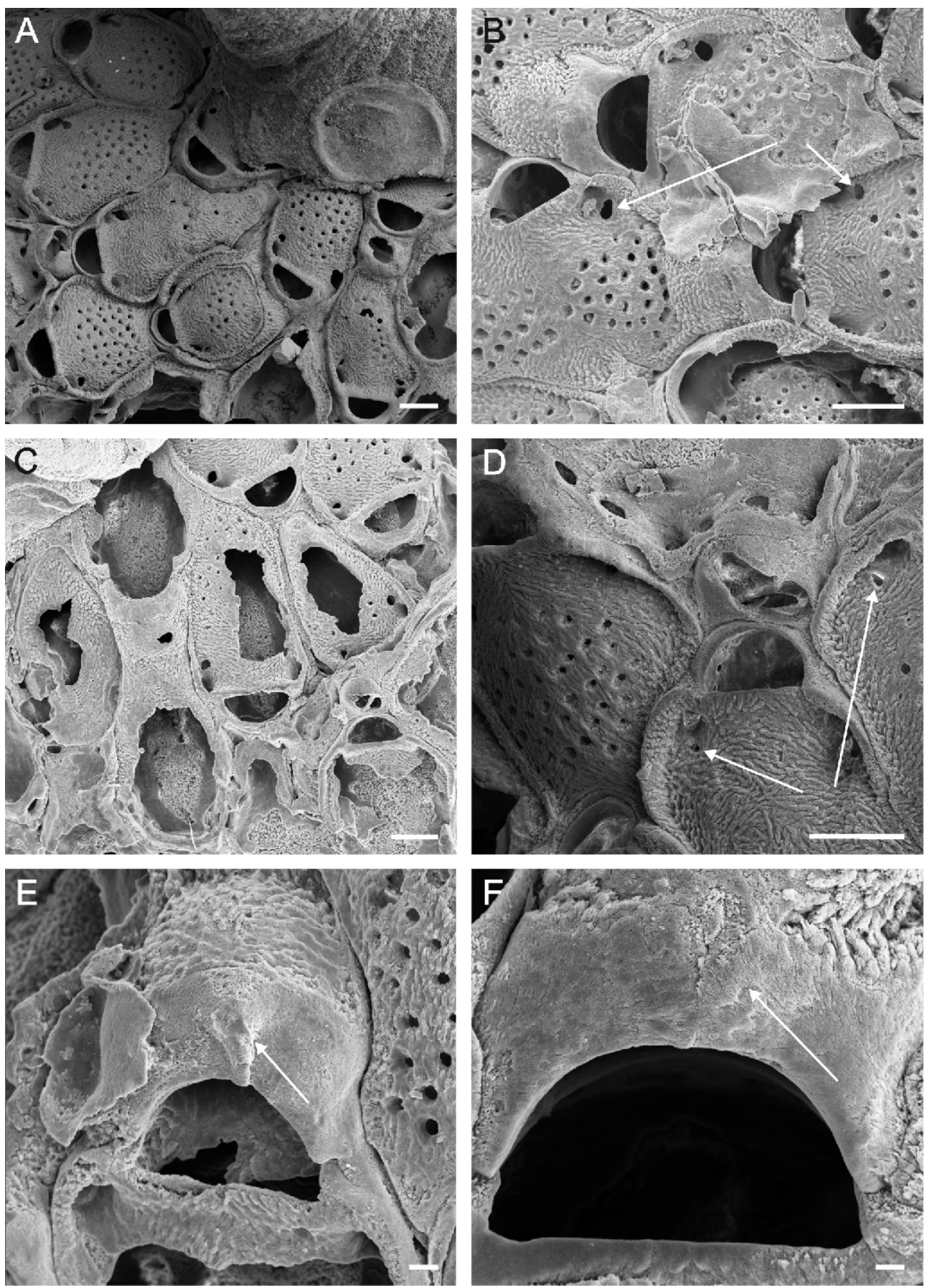

Fig. 5. Micropora nordenskjoeldi sp. nov. specimen numbered By $24211 \mathrm{~h}$, locality IAA 1/90, Telm5, La Meseta Formation, Seymour Island, James Ross Basin, Antarctic Peninsula, Eocene

A - general view of the colony encrusting the external surface of serpulid worm, scale bar $200 \mu \mathrm{m}$; B autozooecia showing the ovicellate zooids with a low knob, as well as one unovicelled autozooecium and the opesiules with small pores (arrowed), scale bar $100 \mu \mathrm{m}$; C - a worn part of a colony and some avicularia, scale bar $100 \mu \mathrm{m}$; D - roughly hexagonal autozooecia, separated by distinct sutures, showing cryptocysts with large pores and the distolaterally placed oval-shaped avicularium with the pointed triangular rostrum; opesiules with small pores (arrowed), scale bar $100 \mu \mathrm{m}$; E - ovicell with a granular structure in the distal part with a broad rim and a indistinct knob, which in the proximal part shows a transversally running tube (arrowed), scale bar $20 \mu \mathrm{m} ; \mathbf{F}$ - proximal part of the ovicell showing the lamellae with a low indistinct knob in the middle, scale bar $10 \mu \mathrm{m}$ 
R e m a r k s. - Two distinct Recent species of Micropora Gray, 1848, described from Antarctica, M. notialis and $M$. brevissima, differ from the La Meseta specimen in a number of morphometric and morphological characters. They both have larger zooecia and avicularia, as well as longer ovicells. Micropora nordenskjoeldi sp. nov. shows great variation in the shape and size of the zooecia, and in the number of pores on the cryptocyst. The very characteristic feature of the specimen studied is the shape of the ovicell, which is short in length and has a small rounded knob placed centrally in the proximal part of the ooecium. In one case, the knob shows a vertical tube, which may be caused by the interference of another organism (?) (see Fig. 5E).

M. elegans Maplestone, 1901 (Maplestone, 1901: 205, pl. 34, fig. 4), described from the Late Eocene of SE Victoria (Australia), is similar to M. nordenskjoeldi in showing great variability in the width and length of the zooecia. It differs from $M$. nordenskjoeldi in slightly different location of the avicularia, which are distal to many zooids, as well as in the lack of the additional pore just proximal to the opesiules, which does not occur in M. elegans (Gordon, 1984: 53, PI. 15B; cf. Maplestone, 1901: 205, pl. XXXIV, fig. 4). The ovicell of $M$. elegans does not possess the characteristic knob present in the specimen studied, and Maplestone's figure appears to show a more globular ovicell with a narrow bifenestrate band along the proximal edge (see also Brown, 1952: 128).

Another species, Micropora variperforata Waters, 1887, shows an irregular series of comparatively large pores developed around the margins of the cryptocyst as well as a crenulated mural rim, and therefore differs from $M$. nordenskjoeldi. According to Gordon (1986), if conspecific with $M$. elegans, this species would be a senior synonym of $M$. elegans, as illustrated by Gordon (1986: PI. 27B; see also Waters, 1887: pl. VIII. fig. 27).

The earliest Eocene Micropora quadriporosa Gordon and Taylor, 1999, described from the Red Bluff Tuff of Chatham Island (Gordon and Taylor, 1999: 17, figs. 38, 39), has four circular opesiules situated in the distal and proximal part of the cryptocyst. The Recent species Micropora gracilis (Uttley, 1949: 174, pl. XXXVI, fig. 2), also described from New Zealand, has 3-5 small rounded accessory opesiules on each side. Moreover, the recently described Micropora chathamica sp. nov. (Gordon and Taylor, 2015: 42, fig. 30D, E) has a distinctly carinate ovicell, quite unlike that of $M$. nordenskjoeldi. The very characteristic features of the new species described here are the small-sized zooecia and ovicells, as well as the possession of one pair of opesiules, together with a single circular pore, just proximal to it, and a low, small knob in the proximocentral part of the ovicell (on the marginal rim; however, as shown in the Fig. 5E, its occurrence is not constant). A small tube running vertically is seen (see Fig. $5 E$ ).

O c c u r r e n c e. - IAA 1/90 (Ungulate Site), Natica Horizon (Telm5); La Meseta Formation, Seymour Island, James Ross Basin; Eocene.

Family Lunulitidae Lagaaij, 1952

Genus Lunulites Lamarck, 1816

Type species. Lunulites radiata Lamarck, 1816

Lunulites marambionis sp. nov.

(Fig. 6)
Holotype: Specimen NRM-PZ By 24207ah, illustrated in Figure 6A, B, E-G.

Type horizon: Natica Horizon, Cucullaea I Allomember (Telm5), La Meseta Formation, Eocene.

Type locality: IAA 2/95 (Marsupial Site), Seymour Island, James Ross Basin, Antarctic Peninsula.

$\mathrm{M}$ a t e ri a I. - One, well-preserved specimen, holotype NRM-PZ By 24207 ah, broken in the middle part with incomplete proximal area, and 22 fragments of colonies, NRM-PZ By 141133a (IAA 2/95) and NRM-PZ By 24209a (IAA 1/90).

E t y m o l o g y. - Named after the Argentinian Antarctic base Vicecomodoro Marambio on Seymour Island.

$\mathrm{M}$ e a sure me nt s. - Length of the colony $5.0 \mathrm{~mm}$, width $6.0 \mathrm{~mm}$, height $0.75 \mathrm{~mm}$, thickness $0.50 \mathrm{~mm}$. Length of zooecia $0.35-0.42 \mathrm{~mm}$ and width $0.25-0.32 \mathrm{~mm}$. Length of opesia $0.15-0.20 \mathrm{~mm}$, width $0.15-0.20 \mathrm{~mm}$. Length of avicularia $0.20-0.30 \mathrm{~mm}$, width $0.07-0.10 \mathrm{~mm}$. Diameter of the basal pores $0.02-0.05 \mathrm{~mm}$.

D e s c ri pti o n. - Colony fan-shaped, medium-sized, regenerated, with a median fracture of the specimen (Fig. 6A, $B$ ); the frontal surface is fairly flattened, composed of 10 straight linear radiating rows of autozooecia, placed medially; six of them arise from the proximal part of zoarium and they are composed of 10-12 autozooecia; among them there are four shorter ones composed of 2-5 autozooecia (Fig. 6A, E, F). Two lateral, symmetrically placed groups of shorter rows of secondary autozooecia are directed more or less perpendicular to the longer medial autozooecia (Fig. 6A, E, F); they are composed of 12-13 rows of autozooecia, each with 1 to 5 autozooecia. The autozooecia are rectangular in shape, slightly longer than wide (Fig. 6D-F, J, K). Cryptocyst granular and convex with a raised proximal border (Fig. 6J, K). Opesia relatively large, occupying more than half of the cryptocyst, rectangular to roughly bell-shaped; often with a horseshoe-shaped proximal margin (Fig. 6J, K). Half of the opesia in the proximal (older) part of the colony is sealed off by a cryptocystal closure plate, perforated by four elongated pores (Fig. 6E, F). The rows of autozooecia are separated by distinct grooves, with continuous single linear rows of avicularia, appearing in annular arrangement from the proximal margin (Fig. 6E, F). Avicularia distinct, elongated, slightly asymmetrical, with a well-developed proximally placed cryptocyst with a denticulate margin (Fig. 6L). A pair of lateral distinctive, long, not fused condyles directed proximally is situated in the middle part of the avicularia (Fig. $6 \mathrm{~J}-\mathrm{L}$ ). Eight rows of avicularia are in the middle part of the colony; each row includes from 1 to 9 avicularia; among the 9 to 11 secondary rows of avicularia there are 1-3 avicularia per row (Fig. 6A). Ancestrula unknown. About fifty distinct roughly straight, but not regular radial lines, corresponding to the distribution of the autozooecial rows, are on the thickened, nearly flat basal surface (Fig. 6B, C, $H$ ). The radial sectors are separated by approximately straight grooves and perforated by 1-2 rows or scattered irregularly large pores, variable in size and shape, but generally with a rounded outline (Fig. 6G-I) and a diameter of 0.02-0.05 mm.

$\mathrm{R}$ e $\mathrm{m}$ a r k s. - Bryozoans of the family Lunulitidae Lagaaij, 1952 , have a long history extending from the Cretaceous to the Recent, with a wide distribution, which includes the European and Indo-Pacific Tethyan, as well as the African, American and Australasian regions. According to Håkansson and Voigt (1996: 190), Lunulites Lamarck includes mostly circular, radially budded zoaria, of more or less flattened conical-shaped forms (Lagaaij, 1952: pls. II, III; Håkansson and Voigt, 1996: figs. 3, 

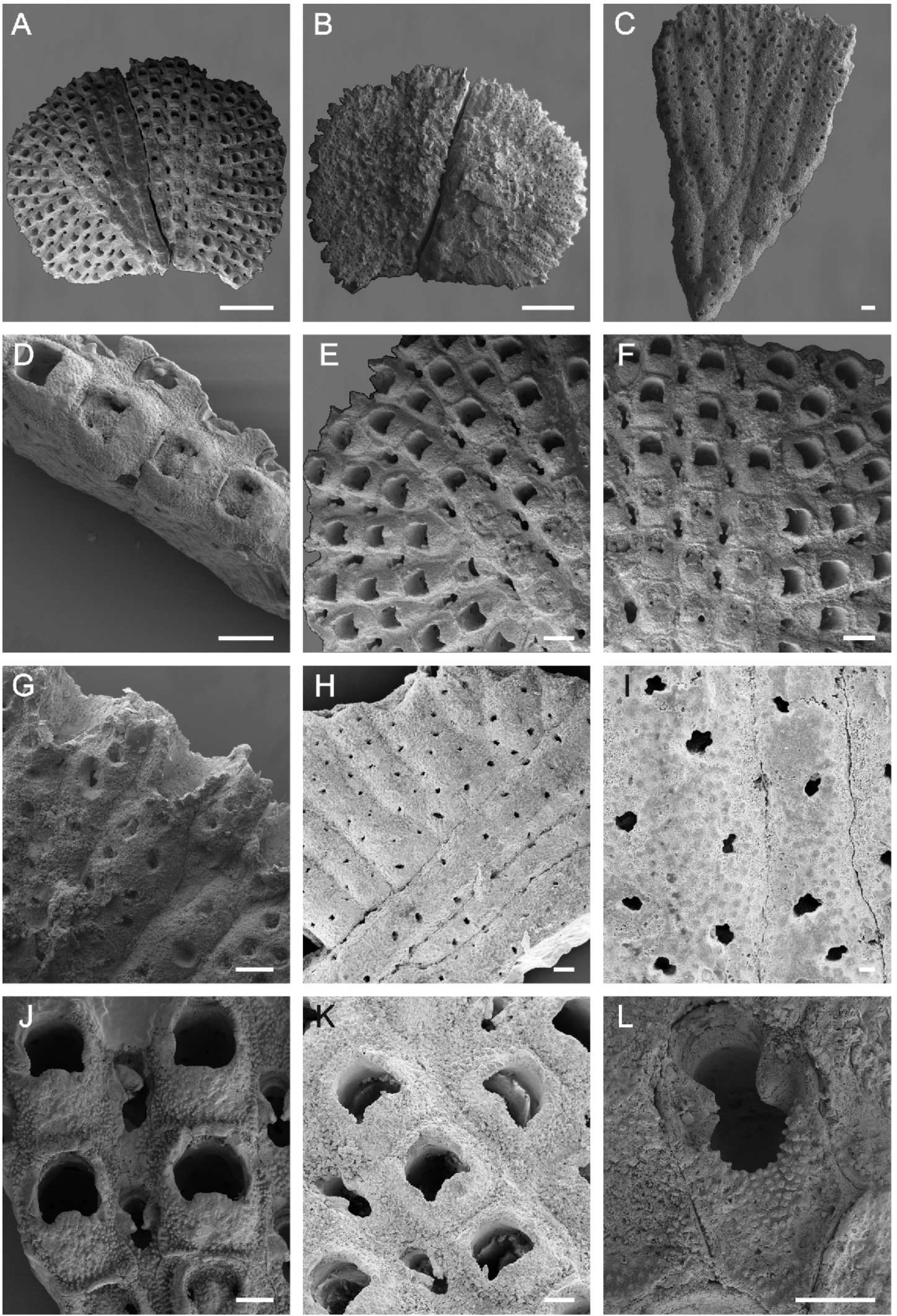

Fig. 6. Lunulites marambionis sp. nov. Telm5, La Meseta Formation, Seymour Island, James Ross Basin, Antarctic Peninsula, Eocene

A - frontal wall of the fan-shaped, regenerated zoarium; B - reverse side of the same zoarium; A, B - scale bar $1 \mathrm{~mm}$, holotype By 24207 ah, horizon IAA 2/95; C - back side of a fragment of zoarium, showing the irregularly running lines with large pores, scale bar $100 \mu \mathrm{m}$, By 24207 a, Telm4; D - a single row of autozooecia with adjacent avicularia, scale bar $200 \mu \mathrm{m}$, By 141133a, locality IAA 2/95; E - growing margin of the regenerated colony, showing the alternating rows of autozooecia and avicularia; $\mathbf{F}$ - central part of a colony with autozooecia and avicularia; $\mathrm{E}, \mathrm{F}$ - scale bar $200 \mu \mathrm{m} ; \mathbf{G}$ - fragment of the growing margin from the reverse side of the colony, showing large pores, scale bar $100 \mu \mathrm{m} ; \mathrm{E}, \mathrm{G}$ - holotype, By 24207 ah, locality IAA 2/95; $\mathbf{H}$ - reverse side of the zoarium, showing the pores arranged in 1-2 rows, or irregularly scattered ones differentiated in size and shape, scale bar $100 \mu \mathrm{m} ; \mathbf{I}$ - reverse side of the zoarium, covered by large pores, scale bar $20 \mu \mathrm{m} ; \mathbf{J}$ - two rows of autozooecia showing the opesia and avicularia, scale bar $100 \mu \mathrm{m} ; \mathrm{K}$ - bell-shaped autozooecia with raised proximal part and a fragment of row with aviculariua, scale bar $100 \mu \mathrm{m} ; \mathrm{H}, \mathrm{K}$ - By 141133a, locality IAA 2/95; L - details of avicularium showing not fused condyles; the extensive proximal part with the serrated margin and well-defined boundaries, scale bar $50 \mu \mathrm{m}$, By 24209a, locality IAA 1/90 
$4,8)$. The majority of Lunulites species have been described from the Paleogene and Eocene (Ypresian-Priabonian) of Europe and America, with just a few species known from the Neogene (Miocene) of SE Australia. Lunulites (Heteractis) barbosae (Buge and Muniz, 1974), which was reported from the Paleocene of Brazil, similarly to the studied specimen, demonstrates a regenerated flabelliform type of zoarium (Buge and Muniz, 1974: pls. I, II). Another example of regenerated colonies is Lunulites vaspertilio (Håkansson and Voigt, 1996: 194-195, fig. 5A, B) from the Late Maastrichtian of the North Sea Basin and the Eocene (Bartonian) Lunulites quadrilaterata Canu and Bassler, 1929 from Belgium (Dartevelle, 1932: pl. II, figs. 3-5). Cook and Chimonides (1985a: 351-353, figs. 14, 15 and 8,17 ) described Lunulites biformis MacGillivray and Lunulites rutella (Tenison-Wood) that range from the Lower Oligocene to the Middle Miocene of SE Australia. They both demonstrate dome-shaped colonies, contrary to L. marambionis sp. nov. (Fig. 6A, B); however, similarly they have a very regular pattern of arrangement of the frontal wall. On the other hand, they differ in many morphological and morphometrical features from the La Meseta specimens. Lunulites rutella has wider and longer autozooecia and avicularia, and L. biformis shorter autozooecia than those described for L. marambionis. Lunulites transiens Gregory, 1893, recorded from the Late Eocene of England (Gregory, 1893: 233-234), also shows the regularly running sectors with zooecia, alternating with single rows of avicularia, particularly those which are placed medially. The basal side of this species (Gregory, 1893: 233-234, pl. XXIX) bears many similarities with the presently studied $L$. marambionis sp. nov., such as the ridges, which are not so regularly distributed and separated by deep grooves. Contrary to $C$. marambionis the numerous pores on the basal wall of $L$. transiens are arranged in a single line, but they can also be arranged more or less irregularly. Although the studied material is represented only by one almost completely preserved specimen, along with many incomplete, fragmented zoaria, their morphological features are distinctive enough to define a new species. The new species represents the first fossil record of this taxon from Antarctica.

O c c u r re n c e. - IAA 2/95 (Marsupial Site), IAA 1/90 (Ungulate Site), Natica Horizon (Telm5); NRM 1, Telm4 (one specimen), La Meseta Formation, Seymour Island, James Ross Basin, Eocene.

Family Otionellidae Bock and Cook, 1998

Genus Otionellina Bock and Cook, 1998

Type species. Otionella australis Cook and Chimonides, 1985 Otionellina antarctica sp. nov. (Fig. 7)

Holotype: Specimen NRM-PZ By 141134ah1, illustrated in Figure 7A, E, F.

Type horizon: Natica Horizon, Cucullaea I Allomember (Telm5), La Meseta Formation; Eocene.

Type locality: IAA 1/90, (Ungulate Site), Seymour Island, James Ross Basin, Antarctic Peninsula.

E t y m o l o g y. - Referring to Antarctica, from where the specimens were collected.

$\mathrm{M}$ a t e ri a I. - 30 fragments of colonies, NRM-PZ By 141134ah1, NRM-PZ By 24207 (IAA 2/95), NRM-PZ By 141133a (IAA 2/95), and NRM-PZ By 24211 (IAA 1/90).
Me a surements. - Length of the fragments of the colonies 3.0-3.6 mm, width (max.) $3.8 \mathrm{~mm}$, thickness $0.50-0.75 \mathrm{~mm}$. Length of zooecia $0.35-0.50 \mathrm{~mm}$, width $0.35-0.45 \mathrm{~mm}$. Length of opesia $0.12-0.15 \mathrm{~mm}$, width $0.16-0.20 \mathrm{~mm}$. Length of avicularium $0.30-0.35 \mathrm{~mm}$, width $0.12-0.14 \mathrm{~mm}$; basal avicularium length $0.27-0.30 \mathrm{~mm}$, width $0.14-0.18 \mathrm{~mm}$

D e s c ri p t i o n. - Zoarium fragmented (Fig. 7A), forming small sectors, with an external border semicircular in outline, slightly convex. Ancestrular region abraded, preserving mould of substrate; the specimens mostly thickened and solid basally, rarely without the basal calcification, sand grains often attached. Autozooecia large, rhomboidal in outline, nearly quadrate in the peripheral area with well-marked, narrow, highly raised boundaries (Fig. 7B). Cryptocyst well-developed, finely granular, depressed in the middle (Fig. 7A, B, D). Autozooecial opesia transversely oval, wider than long, or close to D-shaped, or rhomboidal, placed terminally, occupying the larger part on the cryptocyst (Fig. 7A-D). Interzooecial avicularia are arranged in quincunx, but those close to the marginal part of the colony show a radial arrangement; usually one avicularium is surrounded by 4-6 autozooecia (Fig. 7A-C). Avicularia are symmetrical with only a few showing slight asymmetry on the left (viewed frontally); rather deeply set, elongated, with roughly triangular cryptocystal area placed proximally (Fig. 7B-D). Symmetrical thin condyles, never fused (Fig. 7B, D). Basal area solid, finely punctured, composed of numerous irregularly shaped sectors with well-defined margins and 1-2 distinctive irregularly scattered pores in each sector (Fig. 7E). Basal avicularia oval-shaped, arranged oblique to the growing margin (Fig. 7F), distributed sparsely and irregularly in the subperipheral area, and surrounded by an extensive perforated lamina (Fig. 7E). Median condyles rather small, their distal tips blunt, some distance apart, and never fused (Fig. 7F). Secondary calcification clearly seen on the basal side (Fig. 7F) and along the margins of the opesia.

$\mathrm{R}$ e $\mathrm{m}$ a r k s. - The specimens studied show all the characters of the type species of Otionellina australis (Cook and Chimonides, 1985b: 590-592, figs. 11, 12, 23-25; Bock and Cook, 1998: 197; see also Bock and Cook, 1999: 423, 424). The Late Eocene Australian fauna includes four fairly disparate species of Otionellina: O. cupola, O. exiqua, O. australis, and O. paradoxa. According to Cook and Chimonides (1985a) the early astogenetic pattern of $O$. australis is consistent and distinctive, and its close relationship with Lunulites seems unlikely. Colonies of $O$. australis from Tandarook Bird Rock and Browns Creek show a wide range in the size of zooecia. It is similar to the new La Meseta Formation species, in which great variations in the size of the zooecia and opesia as well as in the shape of opesia occur, but the main difference between $O$. antarctica and $O$. australis is the larger width (in $O$. antarctica $0.35-0.50 \mathrm{~mm}$; in $O$ australis $0.26 \mathrm{~mm}$ ) and length (in $O$. antarctica $0.35-0.45 \mathrm{~mm}$; in 0 . australis $0.18 \mathrm{~mm}$ ) of the autozooecia and the width of the opesia (in $\mathrm{O}$. antarctica $0.16-0.20 \mathrm{~mm}$; in 0 . australis $0.12-0.15 \mathrm{~mm}$ ), but the slightly smaller width of the avicularia in $O$. antarctica sp. nov. (see Cook and Chimonides, 1985b: 589-592). The serrated proximal rims of the opesia in $O$. australis do not occur in $O$. antarctica sp. nov. On the other hand, O. antarctica sp. nov. is very similar to $\mathrm{O}$. zelandica in the distributional pattern of the avicularia. However, the avicularia of $O$. zelandica are longer and broader and slightly asymmetrical, distally as well as they have larger condyles than in O. antarctica sp. nov. Fossil colonies of $O$. australis have a wide stratigraphical distribution and they have been recorded from the Late Eocene and Miocene of 

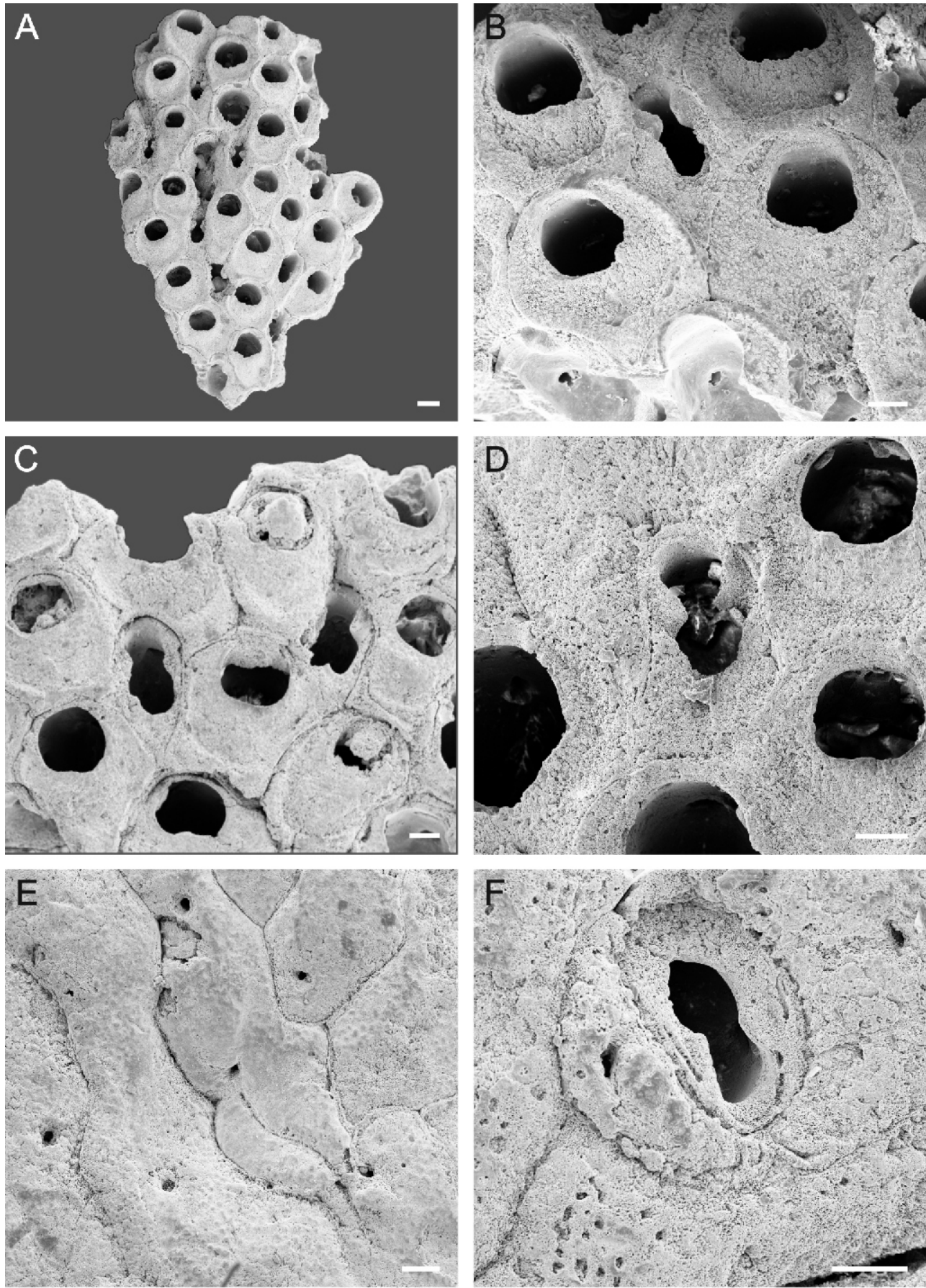

Fig. 7. Otionellina antarctica sp. nov. Telm5, La Meseta Formation, Seymour Island, James Ross Basin, Antarctic Peninsula, Eocene

A - part of the colony from the frontal view, scale bar $200 \mu \mathrm{m}$; B - avicularium surrounded by five zooecia, scale bar $100 \mu \mathrm{m} ; \mathrm{A}, \mathrm{B}$ - specimen numbered 141134ah1, IAA 1/90, Ungulate Site; C - fragment of the margin of the colony showing the neighbouring avicularia at the border of the colony, By 141134a, locality IAA 1/90, Ungulate Site; D - detail of avicularium with unfused condyles, surrounded by five autozooecia (four autozooecia seen on the picture); C, D - scale bar $200 \mu \mathrm{m}$; E - basal side showing irregularly scattered, rare large pores; $\mathbf{F}$ - an oval-shaped, large, subperipheral avicularium on the back side of the colony; E, F - scale bar $100 \mu \mathrm{m}, \mathrm{D}, \mathrm{F}$ - specimen By 141133a, locality IAA 2/95, Marsupial Site 
Victoria to the Pliocene of Western Australia, as well as the Recent of Western Australia and Bass Strait. O. zelandica is known from the Late Oligocene to the Late Miocene of Australia and from Early to Middle Miocene of New Zealand. O. antarctica sp. nov. slightly resembles $\mathrm{O}$. zelandica Cook and Chimonides (Cook and Chimonides, 1984: 242, 243, fig. 13; 1985b: 587, fig. 22) in the general pattern of the arrangement of zooecia, but $\mathrm{O}$. antarctica sp. nov. shows longer and wider zooecia, differently shaped opesia, narrower avicularia, and differently orientated avicularia on the basal wall.

This is the first fossil record of Otionellina from Antarctica, comprising numerous well-preserved fragments of colonies, which are sufficiently different from other Otionellina species (see also Bock and Cook, 1999: 423, 424; Cook and Chimonides, 1985b) and are therefore regarded as a new species.

O c c u r r e n c e. - IAA 1/90, Ungulate Site, Natica Horizon, Cucullaea I Allomember (Telm5); La Meseta Formation, Seymour Island, James Ross Basin; Eocene.

Otionellina eocenica sp. nov. (Fig. 8)

Holotype: Specimen NRM-PZ By 24215h, illustrated in Figure $8 \mathrm{~A}-1$

Type horizon: Natica Horizon, Cucullaea I Allomember (Telm5), La Meseta Formation, Eocene.

Type locality: DPV 6/84, (Rocket Site), Seymour Island, James Ross Basin, Antarctic Peninsula. men

E t y m o l o g y. - Referring the Eocene age of the speci-

M a t e r i a I. - 1 complete colony NRM-PZ By 24215 , locality Rocket Site DPV 6/84, Telm5.

$\mathrm{M}$ e a s u re me nts. - Diameter of the colony $3 \mathrm{~mm}$, thickness $0.65 \mathrm{~mm}$. Length of zooecia $0.35-0.40 \mathrm{~mm}$, width $0.30-0.37 \mathrm{~mm}$. Length of opesia $0.15-0.17 \mathrm{~mm}$, width $0.10-0.12 \mathrm{~mm}$. Length of avicularium $0.17-0.22 \mathrm{~mm}$, width $0.05-0.07 \mathrm{~mm}$.

D e s c ription. - Zoarium free-living, domed-shaped (Fig. 8A, B), roughly circular in outline (Fig. 8C), small, slightly convex (Fig. 8A). Apex of colony shows the ancestrula of the same size than the zooecia (length $-0.37 \mathrm{~mm}$, width $0.32 \mathrm{~mm}$; see Fig. 8C, D). The periancestrular autozooecia, six in number, show the opesiae occluded by closure plates with small pores (Fig. 8D). Autozooecia roughly quadrate in outline; with well-marked, highly raised boundaries (Fig. 8D, E). Cryptocyst well-developed, finely granular, depressed in the middle (Fig. 8E, F), with deeply set opesiae (Fig. 8F). Autozooecial opesia rectangular in shape, placed terminally, occupying the larger part of the cryptocyst (Fig. 8A, C-F). Interzooecial avicularia are arranged in quincunx in the marginal part of the colony; in the middle part, one avicularium is surrounded by five autozooecia (Fig. 8C, E). Avicularia show asymmetry on the left (viewed frontally); deeply set, elongated, wider proximally with roughly triangular, distinct cryptocystal area placed distally (Fig. 8E). Condyles are very small, indistinct and unfused (Fig. 8E). Basal area solid, punctured, showing rare large pores; composed of numerous irregularly shaped sectors with well-defined highly raised margins (Fig. 8G, I). Basal avicularia are not seen (Fig. 8B, G-I). The growing margin from the basal side shows deeply set peripherial zooecia and avicularium (Fig. 8H).
R e marks. - The studied specimens described as Otionellina eocenica $\mathrm{sp}$. nov. show some similarity to $O$. zelandica in size of the zoarium and in a general pattern of the distribution of the zooecia and avicularia. The opesia of Otionellina eocenica sp. nov. are rectangular in shape, contrary to both species of Otionellina zelandica, which show rounded opesia (see Cook and Chimonides, 1985b: 587-589, fig. 22), and described here 0 . antarctica, which possesses D-shaped, nearly rhomboidal opesia (see Fig. 7). The avicularia of Otionellina eocenica sp. nov. are much smaller in width and length than of $O$. zelandica and $O$. antarctica sp. nov., and their shape distinctly differs from those of $O$. zelandica and O. antarctica sp. nov. (see Cook and Chimonides, 1985b: fig. 22; see also Steger and Smith, 2005: fig. 1F). The avicularium of Otionellina eocenica sp. nov. is wider proximally, whereas in O. zelandica, it is wider distally. The distal part of avicularium of Otionellina eocenica sp. nov. is elongated, triangular in shape, contrary to $O$. zelandica. The unfused median condyles of Otionellina eocenica sp. nov. are very small in comparison with those shown by $\mathrm{O}$. zelandica and $\mathrm{O}$. antarctica sp. nov. (compare Figs. 7 and 8; see also Steger and Smith, 2005: fig. $1 F)$. The basal side of both species of $O$. zelandica and O. antarctica sp. nov. reveals irregularly shaped sectors with avicularia on the basal wall, which are also irregular in O. eocenica sp. nov.; however, the basal wall of the specimen studied (see Fig. 8A-I) has no extrazooidal basal calcification. Another Upper Eocene-Upper Miocene species of $O$. exigua (Cook and Chimonides, 1985b: 596, figs. 8, 21, 28) and the Recent one O. minuta (see Cook and Chimonides, 1985b: 592, figs. $10,30,34$ ) show also very narrow avicularia, but they differ in many morphological features such as smaller dimensions of the colony, opesiae and zooecia in length and width. O. exigua from Victoria, similarly as the Antarctic specimen studied, also shows the lack of extrazooidal basal calcification, which may be suggested as a leaching or dissolution of the aragonitic layer (see also Greeley, 1969). The studied specimen shows different morphological and morphometrical characters to be easily distinguished from $O$. zelandica and described here $O$. antarctica sp. nov., as well as from the other Otionellina species to which it was compared (see Cook and Chimonides, 1985b). Therefore, this fully characterized specimen deserves the new name (see Fig. 8A-I).

O c c u r r e n c e. - Locality Rocket Site DPV 6/84; Telm5, La Meseta Formation, Seymour Island, James Ross Basin, Eocene.

\author{
Unplaced cheilostomes \\ Superfamily Adeonoidea Busk, 1884 \\ Family incertae sedis
}

Genus Goodonia Bishop and Hayward, 1989

Type species. - Goodonia cookae Bishop and Hayward, 1989 ?Goodonia sp.

(Fig. 9D-I)

1997a. Smittina Norman; Hara: 1004, fig. $2 f$

2001. Smittina sp.; Hara: 80, PI. 23: 1-4.

Material. - Two large colonies, NRM-PZ By 141128-141129.

Dimensions. - Length of colony $74 \mathrm{~mm}$, height $25 \mathrm{~mm}$. Length of zooecia $0.75-1.0 \mathrm{~mm}$, width $0.25-0.32 \mathrm{~mm}$. Length of orifice $0.12-0.16 \mathrm{~mm}$, width $0.12-0.20 \mathrm{~mm}$. 



Fig. 8. Otionellina eocenica sp. nov. By 24215, locality Rocket Site DPV 6/84, Telm4-5

A - a free-living round-shaped colony, showing the frontal wall; B - view of the back-side of the same colony; C - close up of the frontal view showing the pattern of arrangement of zooecia, with the ancestrula in the middle part (arrowed); A-C - scale bar $1 \mathrm{~mm}$; D - central part of the same colony with the ancestrula (arrowed), scale bar $500 \mu \mathrm{m} ; \mathbf{E}$ - growing margin, showing the neighbouring avicularia at the border of the colony, scale bar $500 \mu \mathrm{m} ; \mathbf{F}$ - detail of zooecium showing the depressed central area with raised margin, scale bar $200 \mu \mathrm{m} ; \mathbf{G}$ - basal side showing irregularly scattered, rare large pores; $\mathbf{H}$ - growing margin from the basal side; G, H - scale bar $300 \mu \mathrm{m} ; \mathbf{I}$ - detail of mould of basal wall, scale bar $100 \mu \mathrm{m}$ 
D e s c r i p t i o n. - Colonies are erect, forming bilamellar rosette-like, broad lobate fronds, or strap-like branches, often anastomosing, 1.1-1.5 $\mathrm{mm}$ in thickness (Fig. 9D, I). Zooecia are elongated to roughly hexagonal, arranged alternately in longitudinal rows, separated by threads seen on the zoarial surface of the frontal wall (Fig. 9E, G). In some parts of the frontal wall the zooecia are bordered by marginal areolae, which seem to encroach onto the centre of the frontal wall due to the secondary thickening. Frontal shield rather thick, slightly convex (Fig. 9F, G). Orifice lies very close to the distal end of zooecia and is bordered by a very shallow peristomial shelf, situated proximally, which is not seen in each autozooecia (Fig. 9F). Some zooecia are also more or less semicircular to circular in shape; in some of them the orifices appear to be slightly sinuate (see Fig. 9G). Avicularia not seen (Fig. 9F). There is no orifice at the narrowing base of the zoarium, which is covered by a system of longitudinal ridges and grooves with some small pores. Sometimes, the zoarial surface appears more like older parts of the colony in which secondary calcification has obscured zooidal boundaries and occluded orifices (see Fig. 9E, H).

$\mathrm{R}$ e $\mathrm{m}$ a $\mathrm{r} \mathrm{k} \mathrm{s}$. - The studied colonies, which are developed from the encrusting base and consist of anastomosing bilamellar branches, are tentatively included in the genus Goodonia Bishop and Hayward, 1989, which is represented by one species Goodonia cookae (see Bishop and Hayward, 1989: 44-45, figs. $186-188$ and p. 60-61, figs. 245-247). The studied specimen shows a few common features with Goodonia, such as the possession of the characteristic lobate bilamellar colonies, autozooecia arranged in alternating longitudinal series, the possession of areolae along the lateral margins, the absence of avicularia, as well partly the character of the orifice. Eschara porosa Milne-Edwards, designated as a paratype of Goodonia, was figured by Lagaaij, 1952 (see Lagaaij, 1952: 126-127, pl. 14, fig. 7) and shows similarity to the studied specimens in the general pattern of the zooecia distribution, in the shape of the orifice, as well as in the morphometrical dimensions of the zooecia and orifice. Bishop and Hayward (1989) stated that some zooids of Goodonia show a slight discontinuity of outline on each side of the orifice that may be termed a condyle, but this feature was barely seen in some orifices of the specimen studied due to the poor preservation state.

The proximal margin of the orifice of Goodonia usually arches perpendicular to the frontal surface of the zooids (see Bishop and Hayward, 1989: 60, fig. 246), which is not seen in the specimens studied; however, the proximal peristomial platform is well defined, but not in each orifice.

Eschara porosa Milne-Edwards, as described by Lagaai (1952: pl. 14, fig. 7), shows a slightly mucronate lower lip, not observed in the specimen studied here. However, this feature is also not seen in the figures of Eschara porosa given by Milne-Edwards (1836: pl. 11, fig. 7a-d).

The material studied from the Submeseta Allomember (DPV 13/84, Telm7) is referred to the earlier described colonies from a bryozoan-bearing horizon occurring in fine-grained sandstone at ZPAL 14 (Telm6) of the La Meseta Formation, where an up to $5 \mathrm{~cm}$ thick biostromal layer was recognized (see Fig. 9; Hara, 2001: 40, fig. 4). It contains bryozoans described as Smittina (see Hara, 2001: 80, pl. 23: 1-4), whose identification was based mostly on the lack of details around the orifice as well as the variability in the development of the primary orifice (Hara, 2001: 80). The new colonies collected from DPV 13/84 (Telm7) provide additional details, such as some details in the morphology of the orifices and the possession of distinct frontal areolae arranged in one row around the proximal and lat- eral margins of the zooecia. The studied colonies are tentatively assigned to Goodonia; however, more studies should be made on better preserved materials to confirm the systematic position of this La Meseta bryozoan (see also Lagaaij, 1952: 122-123, pl. 14, fig. 7).

O c c u r r e n c e. - DPV 13/84, Submeseta Allomember (Telm7), La Meseta Formation, Seymour Island, James Ross Island, Eocene.

Superfamily Lepralielloidea Vigneux, 1949

Family Lepraliellidea Vigneaux, 1949

Genus Celleporaria Lamouroux, 1821

Type species: Cellepora cristata Lamarck, 1816 Celleporaria mesetaensis Hara, 2001

(Fig. 9A-C, J-L)

1997a. Celleporaria Lamouroux; Hara: 1004, figs. 3: 9, 4: 3.

1997b. Osthimosia sp. 2; Hara: 118-119, 127, fig. 4: 22.

2001. Celleporaria mesetaensis; Hara: 75-76, pls. 1: 21, 19: 1-4: text-fig. 29 (A1-A2).

M a te rial. - One complete, subspherical colony, NRM-PZ By 141130.

D i m e n si on s. - Height of the colony $15 \mathrm{~mm}$, width $23 \mathrm{~mm}$. Length of zooecium $0.30-0.45 \mathrm{~mm}$, width $0.24-0.27 \mathrm{~mm}$. Length of orifice $0.15-0.16 \mathrm{~mm}$, width $0.16-0.18 \mathrm{~mm}$. Length of spatulate avicularium $0.42-0.45 \mathrm{~mm}$, width $0.20-0.28 \mathrm{~mm}$. Diameter of vicarious avicularium $0.12 \mathrm{~mm}$; width of ovicell $0.21-0.24 \mathrm{~mm}$.

D e s c ription. - Colony subspherical, slightly wider than high (Fig. 9A), composed of a few superimposed layers, which are clearly visible in thin-sections (Fig. 9J-L). Autozooecia are thickly calcified, in some places closely packed with irregular orientation on the zoarial surface (Fig. 9B, C). The primary orifice roughly D-shaped, wider than longer (Fig. 9B, C). The proximal border of the orifice is slightly concave, surrounded by a slightly raised peristome, which is rather narrow and developed regularly around the apertures, and enclosing a rather small, transversely oval, suboral avicularium (Fig. 9C). A pseudosinus is distinct in some zooecia. The whole zoarial surface is covered by small, roughly rounded pores; however, the marginal pores around the peristome are barely seen due to the poorly preserved zoarial surface, which in some places is uneven and coarse. Spatulate avicularia with extensive palatal area and the characteristic narrowing in the middle of the avicularium are rare. Slightly raised, vicarious round-shaped avicularia are also present. Ovicell cucullate, without ornamentation, occurs very rarely. Up to five distinct growth layers are seen in transverse thin section (Fig. 9J), with the layer thickness varying from 1.0 to $2.5 \mathrm{~mm}$. The moniliform wall structure is well seen in thin section (Fig. 9L).

$\mathrm{R}$ e $\mathrm{m}$ a r k s. - The specimen studied bears all the characteristic features of the genus Celleporaria, such as a $D$-shaped outline of the primary orifice and the presence of a suboral avicularium in the peristome, as well as the possession of large spatulate avicularia and much smaller rounded vicarious avicularia. Moreover, the specimen has a large number of small pores distributed across the entire zoarial surface, and the characteristic cucullate ovicell (see also Hara, 2001: 75-76, pl. 21: 1-3).

O c c u r r e n c e. - DPV 13/84, Submeseta Allomember (Telm7), La Meseta Formation, Seymour Island, James Ross Basin, Eocene. 



Fig. 9A-C, J-L - Celleporaria mesetaensis Hara, 2001; D-I - ?Goodonia sp. La Meseta Formation, Seymour Island, James Ross Basin, Antarctic Peninsula, Eocene

A - upper surface of the round-shaped colony, scale bar $6 \mathrm{~mm}$; B - arrangement of autozooecia, scale bar $100 \mu \mathrm{m}$; $\mathbf{C}$ - worn zoarial surface with autozooecia, and large spatulate avicularium, scale bar $200 \mu \mathrm{m}$; D - upper surface of the rosette-like colony composed of bilamellar, lobate branches, scale bar $1.7 \mathrm{~cm}$; E - worn zoarial surface, scale bar $200 \mu \mathrm{m} ; \mathbf{F}$ - group of autozooecia, showing a subelliptical apertures (arrowed), scale bar $500 \mu \mathrm{m} ; \mathbf{G}$ - growing margin of the colony showing some zooecia, with slightly sinuate apertures (arrowed), scale bar $200 \mu \mathrm{m} ; \mathbf{H}$ - zoarial surface showing the outline of recrystallized zooecia, scale bar $100 \mu \mathrm{m} ; \mathbf{I}$ - vertical section through the bilamellar branches, scale bar $2 \mathrm{~mm} ; \mathbf{J}$ - transverse section through the round-shaped colony, showing layering, scale bar $6 \mathrm{~mm} ; \mathbf{K}$ - transverse section showing the middle part of the round-shaped colony, scale bar $2 \mathrm{~mm} ; \mathrm{L}$ - transverse section showing a growing margin with layering and moniliform zooecial walls, scale bar $1 \mathrm{~mm}$; A-C, J-L - specimen By 141130, W Marambio Basin; D, E, G, H-specimen By 141128; F-specimen ZPAL Br. VIII/A93; I - specimen By 141129; D, E, G, I - SE of Marambio Base; A-E, G-L - Telm7; F - ZPAL 14, Telm6 
Superfamily incertae sedis

Family Brydonellidae Taylor, Casadío, Rosa, and Gordon, 2008

Genus Uharella Taylor, Casadío, Rosa, and Gordon, 2008

Type species. Uharella seymourensis Taylor, Casadío, Rosa, and Gordon, 2008

Uharella seymourensis Taylor, Casadío, Rosa, and Gordon, 2008

$$
\text { (Fig. 10) }
$$

M a t e ri a I. - Around 70 small fragments of encrusting colonies from four samples: NRM-PZ By 24207a and 141133a (IAA 2/95, Marsupial Site, Telm5); NRM-PZ By 24209a, IAA 1/90, Telm5; NRM-PZ By 141132a (IAA 1/93, Submeseta, Telm6); NRM-PZ By 24212 NRM 1, Telm4.

Measurements. - Length of the zooecium $0.48-0.60 \mathrm{~mm}$, width $0.32-0.56 \mathrm{~mm}$. Length of the opesia in early ontogeny $0.28 \mathrm{~mm}$, width $0.12-0.21 \mathrm{~mm}$. Length of the opesia in late ontogeny $0.20-0.24 \mathrm{~mm}$, width $0.14-0.16 \mathrm{~mm}$; diameter of kenozooecia $0.04-0.16 \mathrm{~mm}$.

$\mathrm{D}$ e s c r i p t i o n. - Colony encrusting, forming sheet-like patches of a maximum size of $4.8 \times 2.6 \mathrm{~mm}$ (Fig. 10), multiserial, up to $0.6 \mathrm{~mm}$ thick. Pore chamber lacking. Autozooecia small, elongate rhomboidal (Fig. 10B-D, F-H, J). The younger zooecia are up to $0.60 \mathrm{~mm}$ long and $0.56 \mathrm{~mm}$ wide, overgrown by kenozooecia (Fig. 10A-D, F-H, J, K). Spines absent. Frontal shield umbonuloid, relatively short. Underside of the colony minutely porous (Fig. 10E, I). Opesia varied in shape from oval-shaped (Fig. 10A, B, D) to tear-shaped (Fig. 10C, F-H) and irregularly-shaped (Fig. 9K). Ovicells not seen. Kenozooecia numerous, adventitious, extending over the whole autozooecial frontal wall (Fig. 10A-D, F-H, J, K), but particularly obscured at the zooecial boundaries (Fig. 10C, H, J, K), variable in shape and size. They can be rounded, small (Fig. 10A, D), or polygonal to elliptical (Fig. 10C), or rounded large (Fig. $10 \mathrm{H}-\mathrm{K}$ ); some are restricted to small subcircular or circular holes (Fig. 10B), 0.04-0.06 mm in diameter, and variably disposed on the zoarial surface (Fig. 10B, H, J, K). Basal wall calcified (Fig. 10E, I). Avicularia lacking. Diagenetic processes may have obscured the frontal wall morphology (Fig. 10L).

R e $\mathrm{m}$ a r k s. - According to Taylor at al. (2008b) it is uncertain to which umbonulomorph superfamily the Brydonellidae belongs to, and the recent classification of Gordon (2014) listed it as incertae sedis. Two features distinguishing Uharella from the type genus of the family Brydonellidae are the lack of spines and avicularia (Taylor et al., 2008b); therefore, the superfamily relationship to Brydonellidae is still an open question. The colonies of Uharella seymourensis n. gen., n. sp., described by Taylor et al. (2008b), are epilithozoans encrusting hardened surfaces and separated by strips of unencrusted substrate (Taylor et al., 2008b; Fig. 2). The new material from the middle and upper part of the LMF (Telm4-6) is identified as U. seymourensis because it shows all morphological features of the genus Uharella Taylor, Casadío, Rosa, and Gordon (see Taylor et al., 2008b: 264-265). The colonies of $U$. seymourensis studied here (Fig. 10) form small irregular sheets found in loose sediments, contrary to the materials described from Cucullaea II encrusting hard substrates (Taylor et al., 2008b). The morphological features of $U$. seymourensis, described in this study, show great variability in the length and width of zooecia in late ontogeny, which are both longer and wider than in the specimens described by Taylor et al. (2008b), however, their minimum size is almost the same. The opesia of the specimens examined from the LMF (Telm4-6) show a larger size in early ontogeny than the opesia described by Taylor et al. (2008b). Of note is that the morphology of the frontal wall between the specimens studied and those illustrated by Taylor et al. (2008b) shows a great differentiation in the shape of the opesia, which in the Cucullaea II materials (Taylor et al., 2008b) are more of less subcircular in shape, but in the specimens studied here vary from very regular circular to subcircular (Fig. 10D), through tear-shaped (Fig. 10G, H), to irregular (Fig. 10K). The same phenomenon is observed in the size and shape of kenozooecia, which show greater variations than was observed by Taylor et al. (2008b). The kenozooecia are slightly larger in the presently studied specimens than in $U$. seymourensis described by Taylor et al. (2008b). However, the minimal size of kenozooecia is the same in the Cucullaea I and Cucullaea II assemblages.

O c c u r rence. - Cucullaea I Allomember: NRM 1 (Telm4), IAA 1/90 (Ungulate Site, Telm5), IAA 2/95 (Marsupial Site, Telm5); Cucullaea II Allomember (upper Telm5), see Taylor et al., 2008b; Submeseta Allomember, IAA 1/93 (Telm6), La Meseta Formation, Seymour Island, James Ross Island, Eocene.

\section{MINERALOGY OF THE LUNULITIFORM BRYOZOANS FROM THE LA MESETA FORMATION}

Cheilostomes, ever since they appeared, have evolved in a variety of skeletal mineralogies utilizing calcite or aragonite, whereas others are bimineralic (Taylor et al., 2009). According to the recent mineralogical studies (Taylor et al., 2009), there is a strong inverse latitudinal correlation between aragonite and latitude evident in the cheilostome mineralogy during the late Mesozoic and Paleogene. It is worth stressing that none of the cheilostomes from above $40^{\circ}$ latitude had skeletons made entirely of aragonite (see Taylor et al., 2009). Borisenko and Gontar (1991) drew attention to the scarcity of aragonite and total absence of bimineralic species in the 48 analysed Antarctic and Arctic species. A combined date base of cheilostome mineralogy shows aragonite to be widely distributed across Cheilostomata, occurring in numerous genera and families belonging to the three most diverse subgroups (Flustrina, Umbonulomorpha, and Lepraliomorpha).

The free-living flustrine lunulitiform genera Lunulites and Otionellina are described here from the middle part of the La Meseta Formation (Telm4-5). This fauna dominates among the siliciclastic sediments in the upper part of Telm4 (locality NRM1), and in the Natica Horizon, Cucullaea I (Telm5) in the three localities of IAA 2/95 (Marsupial Site), IAA 1/90 (Ungulate Site), as well as in the DPV 6/84 (Rocket Site; Figs. 1C, 2, 6-8).

Lunulites marambionis sp. nov. and Otionellina antarctica sp. nov. from localities IAA 2/95 and IAA/90 of Telm5 (see Figs. 1, 2, 6-8) were analysed for skeletal mineralogy by using a Cameca $\mathrm{SX}-100$ electron microprobe. The average $\mathrm{MgCO}_{3}$ content of calcite in the La Meseta bryozoans ranged from 4.0 to $5.0 \mathrm{~mol} \%$ with a mean value of $4.5 \mathrm{~mol} \%$. The calcitic bryozoan skeletons of the La Meseta Formation (Telm5) are formed of intermediate-Mg calcite (IMC) with $4.5 \mathrm{~mol}^{2} \mathrm{MgCO}_{3}$ content, for all samples examined. For comparison, the average $\mathrm{MgCO}_{3}$ content of the Cretaceous-Paleocene and Eocene samples ranges from 3.3 to $3.9 \mathrm{~mol} \%$ (see Taylor et al., 2009; see also Bone and James, 1993; James, 1997).

Seven samples, described as 11/16/1-11/16/7 and represented by two taxa of Lunulites marambionis sp. nov. and Otionellina antarctrica sp. nov. from the La Meseta Formation (Telm5), were examined using the X-ray diffraction (XRD). Only in one sample 11/16/2 from IAA 1/90 locality, represented by 

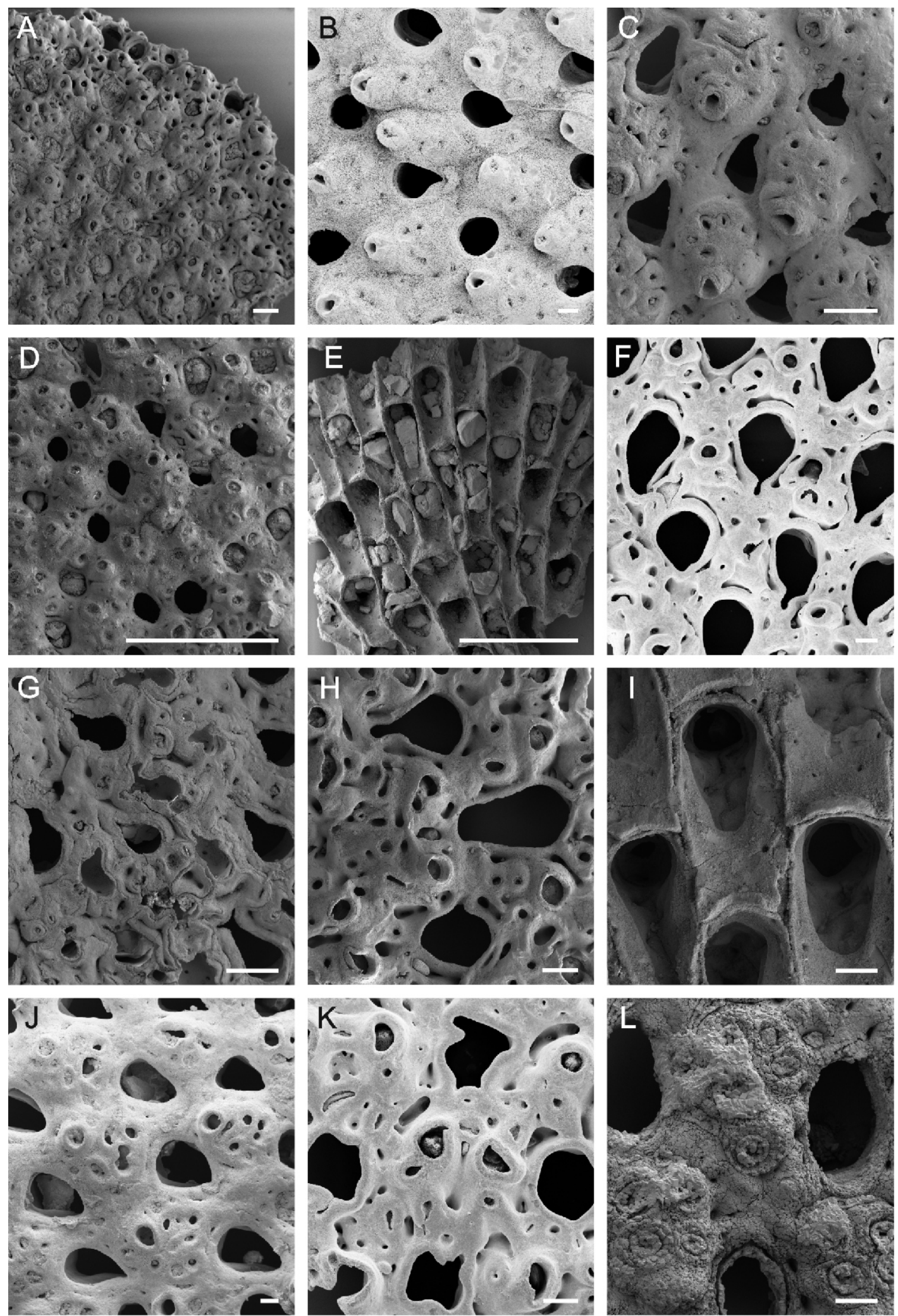

Fig. 10. Uharella seymourensis Taylor, Casadio, Rosa and Gordon, 2008, scanning electron micrographs, La Meseta Formation, Seymour Island, James Ross Basin, Antarctic Peninsula, Eocene

A - growing edge, By 24209a, locality IAA 1/90, Telm5, scale bar $200 \mu \mathrm{m}$; B - part of a colony surface, showing a regular pattern of arrangement of autozooecia and well-marked, prominent subcircular holes of kenozooecia, By 141133a, locality IAA 2/95 (Marsupial Site), Telm5, scale bar $100 \mu \mathrm{m}$; C - old colony surface showing a tear-shaped opesia and smaller well-marked kenozooecia around the autozooecia, By 24212, locality NRM 1, Telm4, scale bar 200 um; D - young autozooecia with numerous round-shaped kenozooecia on the frontal wall; E underside of the colony detached from the substrate, bearing some grains derived from the matrix of substrate; D, E-By 24207a, locality IAA 2/95, Telm5, scale bar $1 \mathrm{~mm} ; \mathbf{F}$ - part of the old colony showing, large opesia of autozooecia, By 141133a, locality IAA 2/95, scale bar $100 \mu \mathrm{m}$, Telm5; G - part of a worn, old colony surface, By 24212, locality NRM 1, Telm 4, scale bar $100 \mu \mathrm{m} ; \mathbf{H}$ - large opesia of the old colony surrounded by large kenozooecia, By 24209a, locality IAA 1/90, Telm5, scale bar $100 \mu \mathrm{m}$; I - few autozooecia showing underside of the gymnocyst separated by a ring scar from the umbonuloid frontal wall with a few pores, By 141133a, locality IAA 2/95, Telm5, scale bar $100 \mu \mathrm{m} ; \mathbf{J}$ - regular pattern of arrangement of zooecia and kenozooecia, scale bar $100 \mu \mathrm{m}$; K - worn zoarial surface showing differently-shaped opesia; J, K - By 141132a, locality IAA 1/93, Telm6, scale bar $100 \mu \mathrm{m}$; L - part of an old colony surface with large opesia and kenozooecia sealed by the sediments, scale bar $100 \mu \mathrm{m}$, By 24207a, locality IAA 2/95, Telm5 
Otionellina antartica sp. nov., small contents of aragonite accompanied by strontium apatite have been found.

Pseudomorphs of calcite after fibrous aragonite were also reported earlier in the carbonate hemispherical skeletons of the bryozoan colonies collected from the Telm1 unit (Sadler, 1988) of the La Meseta Formation (Tatur et al., 2011).

The best examples of the presence of aragonite come from the free-living lunulite cheilostomes, in which aragonite is invariably added either to the outer surfaces of frontal shields or to the undersides of free-living colonies (Greeley, 1969). He showed how so-called basally uncalcified fossil zoaria are believed to result from preferential leaching or solution of the basal aragonite, leaving only the calcitic lateral and frontal walls (see Greeley, 1969: 252, pl. 34, figs. 1-2; see also Fig. 8B, I-H in this paper).

In most bimineralic bryozoan species of the family Otionellidae, aragonite is restricted to the superficial skeleton and acts as a strengthening layer, being less susceptible to physical and chemical destruction than calcite, but especially susceptible to a diagenetic change (Smith and Nelson, 1993; Smith et al., 1998; Steger and Smith, 2005).

The lunulitiform Otionellina sp., described here, has only the frontal side preserved and shows an external mould of the basal side (see Fig. 8). This partial mould is a useful indicator of an originally bimineralic composition of this taxon, which may also suggest that aragonite was lost via dissolution (see also Greeley, 1969; cf. Busk, 1859).

With respect to the mineralogical results reported here for the apparently bimineralic skeleton of Otionellina, the use of Laser Raman spectroscopy, allowing a submicron level of in-situ mineralogical determination, would be helpful to examine the distribution of calcite and aragonite within the free-living La Meseta Formation bryozoans (see also Taylor et al., 2008a).

The studied specimens of Otionellina of Ypresian or Ypresian/Lutetian age from the middle part of the La Meseta Formation (Cucullaea I Allomember, Telm5), which contained traces of aragonite verified by XRD analyses, pre-dated those found in the Lutetian (Middle Eocene) rocks. However, aragonite was acquired by several groups at different times during the late Mesozoic and Paleogene (see Taylor et al., 2009).

\section{DISCUSSION}

The bryozoans from the middle and upper part of the LMF (Telm4-7), dated as the Early Eocene to Late Eocene (Upper Ypresian-Priabonian), include nine species represented by cyclostomes and cheilostomes, mostly anscan flustrine, umbonulomorphs and lepraliomorphs. Bryozoans are, however, scarce compared to their abundant occurrence in the lower part of the formation (Telm1; see Hara, 2001, 2002, 2015).

The earlier Cenozoic Southern Hemisphere bryozoan records, which pre-date the La Meseta bryofauna, derived from uppermost Paleocene-lowermost Eocene rocks consisting of a calcareous palagonite tuff of basaltic composition, with beds of lapillistone and tuff-breccia on Chatham Island, New Zealand (Gordon and Taylor, 1999, 2015; cf. Hara, 2001, 2002). Middle to Late Eocene bryozoans from the St. Vincent Basin in southern Australia were studied by Schmidt and Bone (2001), who reported more than 250 species, although only a small proportion of these species have been formally described.

The occurrence of distinct, free-living lunulitiform bryozoans, which developed disc-shaped colonies, is characteristic of the middle part of the LMF (Telm5). This fauna is represented by the genera Lunulites and Otionellina that live on unstable loose, granular substrata, where they are common (Cheetham, 1963), and therefore they are overwhelmingly associated with sand fauna settings (see also Cook, 1963; Lagaaij, 1963; Greeley, 1969; McKinney and Jackson, 1989; Rosso, 1996; O'Dea et al., 2004, 2008, 2011; O'Dea, 2009). Environmentally, lunulitids occur in shallow shelf conditions $(2.5-190 \mathrm{~m})$, with temperatures of $10-29^{\circ} \mathrm{C}$, on coarse, sandy to muddy bottoms, with low to moderate deposition, in quiet to agitated regimes. They are absent in rocky areas with high turbulence and high silt deposition, in coarse shell or pebble beds, in water with salinities $>37 \%$, and/or bottom temperatures consistently lower than ${ }^{10}-12^{\circ} \mathrm{C}$ (Cook, 1963, 1979; Cook and Chimonides, 1983; O'Dea et al., 2008, 2011; O'Dea, 2009). Free-living lunulitiforms such as Lunulites and Otionellina may, like benthic foraminifera, immediately become transformed into sediment grains on death, and generally need no substrate to grow on except for small-sized grains of quartz or other skeletal material for settlement of the larvae (Cadée, 1975, see also Bałuk and Radwański, 1977; O'Dea et al., 2008). Fragmentation of lunulitiform species is significant in fossil and Recent populations (Dartevelle, 1932; Buge and Muniz, 1974; Bałuk and Radwański, 1977; O’Dea et al., 2004; O’Dea, 2009); however, the causes of this phenomenon remain to be clarified. Most common is mechanical fragmentation of existing colonies, often into triangular wedge-shaped pieces, followed by regrowth from the edges of the fragments to restore a near-circular colony outline (cf. Fig. 6; see also O'Dea et al., 2008, 2011; O'Dea 2009). On the other hand, free-living colonies are most often recovered as complete skeletons, forming a coarse fraction in muddy or silty sediments (Cook and Chimonides, 1983; see also O'Dea et al., 2004). In the middle part of the LMF (Cucullaea I Allomember), lunulitiforms are entirely composed of regenerated or fragmented colonies (Figs. 6 and 7); however, one exception is a colony of Otionellina eocenica sp. nov. with a basal wall preserved as a mould, which has been found in the Rocket Site (DVP 6/84) locality in Telm4-5 (see Figs. 1C, 2 and 8).

For palaeonvironmental analysis the presence of free-living bryozoans (Lunulites and Otionellina) can be informative particularly for the temperate shelf environment, sandy, often shifting substrate, and diagenetic history that allows for preservation of aragonite. According to Smith et al. (2006), it is tempting to speculate that an abrasive lifestyle among the sand grains requires the use of stronger and denser aragonite, which may reflect the colonization of high-energy shifting substrates by benthic bryozoans.

Lunulitidae were first studied from the Oligo-Miocene Victorian deposits in the Tertiary basins of Australia (MacGillivray, 1895; Brown, 1952; Cockbain, 1971; Cook and Chimonides, 1986; Bock and Cook, 1995, 1998, 1999, 2002). Living species are known only from Australasian sand fauna environments, but their predecessors were equally abundant in Cretaceous to Paleogene seas of Europe and in Eocene seas of North and Central America (see Cheetham, 1963; Lagaaij, 1963). According to Schmidt and Bone (2001), Australasian Otionellina or Otionella form a large complex and diverse fauna, which probably derived from an Eocene circum-Antarctic ancestor. In the light of the first fossil record of the austral Otionellina from the LMF of Seymour Island this may suggest the Antarctic origin of this taxon. During the Late Oligocene, the establishment of a circum-Antarctic current resulted in glaciations and a catastrophic fall in sea temperatures. This is inferred to have isolated the Miocene lunulitiform faunas of South America and Australia, and to have caused the extinction of the intervening Antarctic shelf fauna (Schmidt and Bone, 2001).

One taxon recognized in the DPV $13 / 84$ locality of Telm7 (SE part of the Marambio Base, see Figs. 3F and 9D, E, G-I) is 
provisionally identified as ?Goodonia. This genus, represented by one species of $G$. cookae, was described from the Pliocene Coralline Crag by Bishop and Hayward (1989: 44, 186-188, p. $60,245-247)$. The Coralline Crag taxon is similar to the bryozoan colonies described from a bryozoan-bearing horizon of a fine-grained sandstone in Telm6 at ZPAL 14 (Cucullaea II Allomember, see Hara, 2001: 80, pl. 23; Fig. 9F), where a biostrome layer up to $5 \mathrm{~cm}$ thick was recognized, along with a few poorly preserved sole fragments of bryozoan colonies, associated with vertebrates such as penguins and gadiform fish remains in Telm7 at ZPAL 3 (Borsuk-Białynicka, 1988; Myrcha et al., 1990; Jerzmańska and Świdnicki, 1992; Hara, 2001: 40). The large bilamellar colonies of ?Goodonia, which form a biostrome, may indicate that the biofacies developed into a non-sedimentation zone of the bypass area on a siliciclastic aphotic shelf, or into a very slow fine-clastic sedimentation, where the numerous filtering organisms, such as bryozoans, colonized the seafloor (see Reguant, 1990).

Four new species, such as Micropora nordenskjoeldi, Lunulites marambionis, Otionellina antarctica and Otionellina eocenica, were recognized in the middle part of the LMF. They all have a different history of origin, both geographically and temporally. Lunulites is known from the Cretaceous (Santonian-Maastrichtian) of Europe and the Upper Eocene (Priabonian) of North America, tropical America, and the Caribbean province (Cook and Chimonides, 1983; see also Rosso, 1996). Micropora is recorded from the Cretaceous of Europe and from the Upper Paleocene-Lowermost Eocene of New Zealand (Gordon and Taylor, 1999, but the austral genus Otionellina extends from the Upper Eocene-Oligocene (Rupelian) of Australia, and it is known from the Miocene of New Zealand (Cook and Chimonides, 1984).

The umbonulomorph Uharella seymourensis, belonging to Brydonellidae, was first described from the Cucullaea II Allomember (Marenssi et al., 1998) of the La Meseta (upper Telm5) and it is found as an epilithozoic bryozoan, forming unilamellar sheets, encrusting the hardened surface composed of pebbles or small cobble-sized lithoclasts (Taylor et al., $2008 \mathrm{~b})$. The colonies of $U$. seymourensis, described in this study, derive from the allomembers of Cucullaea I and Submeseta (Telm4-6), and they are found in the loose residuum of the clastic sediments (Fig. 10).

The relationship between the colony and the substrate on which a bryozoan grows has a fundamental importance because this governs to some extent the way in which sedimentary particles are produced (Stach, 1936; Smith, 1995; Hageman, 1997). In the Cenozoic the dramatic increase of free-living and articulated morphotypes (Taylor and James, 2013) probably reflects the colonization of shallow-water environments with high wave energy. It should be also concluded that the dominant share of lunulitiform colonies in the Cucullaea I Allomember (Telm4-5) may indicate shallow-water conditions for the middle part of the LMF. Similarly, the presence of articulated or rooted colonies and unizooidal and bi-zooidal internodes, whose presence implies a nearshore environment with considerable wave action and warm climatic conditions were documented from the basal facies of the lowermost part of the La Meseta Formation of Telm1 (see Hara, 2015).

Isotope and palaeobotanical data indicate that the sea surface temperature of the Antarctic Eocene marine waters was about the same as in tropical regions (Dzik and Gaździcki, 2001; see also Dutton et al., 2002).

This fauna is richly accompanied by the nektic fish, mostly sharks, rays and chimerid holocephalians, as well as the large thick-shelled bivalve Cucullaea raea, and the thick-shelled gastropods Antarctodarwinella nordenskjoldi and Struthiolarella steinmanni, associated with other marine molluscs, brachiopods, crinoids, starfish, asteroids, sea urchins, nautiloids, balanomorphs and crabs (McKinney et al., 1988; Zullo et al., 1988; Blake and Zinsmeister, 1988; Feldmamn and Wilson, 1988; Stilwell and Zinsmeister, 1992; Cione and Reguero, 1998; Dzik and Gaździcki, 2001; Tatur et al., 2011). The selachian fauna in Telm5 shows the greatest diversity almost equal to present-day tropical faunas (Kriwet and Gaździcki, 2003; Reguero et al., 2013).

Reported for the first time here, the free-living lunulitiform taxa Lunulites and Otionellina, as well as a genus provisionally identified as ?Goodonia, can be valuable climatic indicators, as these genera recently inhabited circumtropical, tropical-subtropical, to warm temperate waters (Lagaaij and Cook, 1973; Bishop and Hayward, 1989). Lunulitiforms are also a group of fossils that evolved aragonite biomineralization, whereas others can also be bimineralic or calcitic (Taylor et al., 2009). The occurrence of aragonite along with strontium apatite was determined by XRD analysis in the studied material. The presence of a mould of the basal wall in one specimen of Otionellina eocenica sp. nov. may suggest that aragonite was added to the basal side of the colony and then leached showing the loss of this part of the skeleton (see Fig. 8B, G, I; see also Greeley, 1969).

The nautiloid assemblage from Telm4 to Telm6 apparently developed in response to the Eocene warming episodes and the resulting transgression of a warm sea (Dzik and Gaździcki, 2001). A sharp decrease in diversity of nautiloids near the contact between Telm5 and Telm6 (Middle Eocene) was probably associated with the climatic cooling event that culminated at the time of deposition of the upper part of the LMF. Above Telm6, no nautiloids are known (Dzik and Gaździcki, 2001). This decline may mark the proximity of the Eocene-Oligocene boundary, when a major decrease in temperature occurred in the southern oceans (Gaździcki et al., 1992). According to Sr isotope stratigraphy the uppermost part of the LMF (top of Telm7) is Late Eocene (34.2 Ma) in age (Dingle and Lavelle, 1998).

The faunistic evidence of the bryozoan fauna studied here (Telm4 to 7), along with their growth-forms and associated faunas, indicate deposition of the LMF in warm temperature conditions of the Ypresian to Priabonian sea highstand termed the Arctowski interglacial, which is consistent with the palaeontological dating of late Early to Late Eocene (Dzik and Gaździcki, 2001; see also Case, 1992; Cione and Reguero, 1998).

It is worth stressing that the evolution of the modern Antarctic bryozoan community structure was initiated toward the end of the Eocene with the start of a major decline in global temperatures, based on evidence from the Late Eocene of Seymour Island (Aronson et al., 1997, 2009; Crame et al., 2014).

Acknowledgements. TM and MR are grateful to the Argentine Antarctic Institute (IAA-DNA) and to the Argentine Air Force, which provided logistical support for fieldwork on Seymour Island. TM thanks the Swedish Polar Research Secretariat (SPFS) for logistical support. We thank M. de los Reyes (Museo de La Plata) for screening and picking, S. McLoughlin (NRM) for Figures 1 and 2, and B. Giblewska (Polish Geological Institute - National Research Institute) for Figures 4-10. The thin-sections were prepared by A. Szumny (Academy of Metallurgy in Cracow). A. Gąsiński (Department of Geology, University of Warsaw) and L. Giro (Polish Geological Institute - National Research Institute) are kindly thanked for the assistance during the SEM sessions. W. Narkiewicz (Central Chemical Laboratory at the PGI-NRI) is thanked for performing the XRD analyses and G. Zieliński is acknowledged for the mineralogical data obtained from the electron microprobe 
(Cameca $S X-100$ ). Special thanks for providing excellent reviews of this manuscript are kindly offered to Prof. R.M. Feldmann (Kent State University, Kent, OH), Dr D.P. Gordon (NIWA, Wellington) and Dr P.D. Taylor (Natural History Museum, London). The Swedish Research Council (VR grant 2009-4447 to TM), the Consejo Nacional de Investigaciones Científicas y Técnicas (CONICET grant PIP 0462 to MAR), and the Argentine National Agency for Promotion of Science and Technology (ANPCyT grant PICTO-2010-0093 to MAR) are gratefully acknowledged for financial support. UH thanks the Scientific Committee on Antarctic Research (SCAR), the International Council for Science and AntEco Programme, particularly to Dr H.J. Griffiths (BAS, Cambridge), Dr E. Griffin (Scott Polar Research Institute, Cambridge) and Prof. J. Strugnell (La Trobe University) for the financial support (travel grant) to participate in the XXXIV SCAR OSC in Kuala Lumpur (Malaysia) in 2016. The final stage of the preparation of the manuscript was supported by the Polish Geological Institute National Research Institute by the internal project 61.3608.1503.00.0. Warm thanks are also extended to Prof. T.M. Peryt for the general editorial remarks of the manuscript.

\section{REFERENCES}

Aronson, R.B., Blake, D.B., Oji, T., 1997. Retrograde community structure in the late Eocene of Antarctica. Geology, 25: 903-906.

Aronson, R.B., Moody, R.M., Ivany, L.C., Blake, D.B., Werner, J.E., Glass, A., 2009. Climate change and trophic response of the Antarctic bottom fauna. PLOS One. Doi: 10.1371/journal.pone.0004385

Bałuk, W., Radwański, A., 1977. The colony regeneration and life habitat of free-living bryozoans, Cupuladria canariensis (Busk) and C. haidingeri (Reuss), from the Korytnica Clays (Middle Miocene; Holy Cross Mountains, Poland). Acta Geologica Polonica, 27: 143-156.

Bieńkowska-Wasiluk, M., Bonde, N., Møller, P.R., Gaździcki, A., 2013. Eocene relatives of cod icefishes (Perciformes: Notothenioidei) from Seymour Island, Antarctica). Geological Quarterly, 57 (4): 567-582.

Bishop, J.D.D., Hayward, P.J., 1989. SEM atlas of type and figured material from Robert Lagaaij's 'The Pliocene Bryozoa of the Low Countries' (1952). Mededelingen Rijks Geolgische Dienst, 43: $1-64$

Blake, D.B., Zinsmeister, W.J., 1988. Eocene asteroids (Echinodermata) from Seymour Island, Antarctic Peninsula. GSA Memoir, 169: 489-498.

Bock, P.E., Cook, P.L., 1995. Pachystomaria parvipuncta MacGillivray, a sand fauna bryozoan species from the Tertiary of Victoria. Alcheringa, 19: 171-174.

Bock, P.E., Cook, P.L., 1998. Otionellidae, a new family including five genera of free-living, lunulitiform Bryozoa (Cheilostomatida). Memorie di Scienze Geologiche, 50: 195-211.

Bock, P.E., Cook, P.L., 1999. Notes on Tertiary and Recent 'Lunulite' Bryozoa from Australia. Memoire di Scienze Geologiche, 51: 415-430.

Bock, P.E., Cook, P.L., 2002. First fossil finds of some Australian Bryozooa (Cheilostomata), Alcheringa, 25: 407-424.

Bomfleur, B., Mörs, T., Ferraguti, M., Reguero, M.A., McLoughlin, S., 2015. Fossilized spermatozoa preserved in a 50-Myr-old annelid cocoon from Antarctica. Biology Letters, 11: 20150431. http://dx.doi.org/10.1098/rsbl.2015.0431

Bone, Y., James, N.P., 1993. Bryozoans as a carbonate sediment producers on the cool-water Lacepode Shelf, Southern Australia. Sedimentary Geology, 86: 247-271.

Borg, F., 1944. The stenolaematous Bryozoa. Further Zoological Results of the Swedish Antarctic Expeditions, 3: 1-276.

Borisenko, Y.A., Gontar, V.I., 1991. Mineral composition of skeletons of cold-water Bryozoa (in Russian). Marine Biology, 1 : $80-90$.

Borsuk-Białynicka, M., 1988. New remains of Archaeoceti from Paleogene of Antarctica. Polish Polar Research, 9: 437-445.

Brown, D.A., 1952. The Tertiary Cheilostomatous Polyzoa of New Zealand. British Museum (Natural History), London.
Buge, E., Muniz, G. da C.B., 1974. Lunulites (Heteractis) barbosae, nouvelle espece de Bryozoaire lunilitiforme (Bryozoa, Cheilostomata) du Paleocene du Nord-est du Brasil. Annales de Paleontologie (Invertebres), 60: 191-202.

Buono, M.R., Fernandez, M.S., Reguero, M.A., Marenssi, S.A., Santillana, S.N., Mörs, T., 2016. Eocene Basilosaurid whales from the La Meseta Formation, Marambio (Seymour) Island Antarctica. Ameghiniana, 53: 296-315.

Busk, G., 1859. A Monograph of the Fossil Polyzoa of the Crag. Palaeontographical Society, London.

Cadée, G.C., 1975. Lunilitiform Bryozoa from the Guyana Shelf. Netherlands Journal of Sea Research, 9: 320-343.

Canu, F., Bassler, R.S., 1920. North American Early Tertiary Bryozoa. Bulletin of the United States National Museum, 106: $1-879$.

Case, J.A., 1992. Evidence from fossil vertebrates for a rich Eocene Antarctic marine environment. Antarctic Science, 56: 119-130.

Cheetham, A.H., 1963. Late Eocene Zoogeography of the Eastern Gulf Coast Region. GSA Memoir, 91: 1-113.

Cione, A.L., Reguero, M.A., 1998. An Eocene basking shark (Lamniformes, Cetorhinidae) from Antarctica. Antarctic Science, 10: 83-88.

Cockbain, A.E., 1971. Tertiary Cheilostomatous Bryozoa from Victoria - a revised stratigraphical distribution. Proceedings of the Royal Society of Victoria, 84: 173-178.

Cook, P.L., 1963. Observations on live lunulitiform zoaria of Polyzoa. Cahiers de Biologie Marine, 4: 407-413.

Cook, P.L., 1979. Mode of life of small, rooted "sand fauna" colonies of Bryozoa. In: Advances in Bryozoology (eds. G.P. Larwood and M.B. Abbott): 269-282. Academic Press, London and New York.

Cook, P.L., Chimonides, P.J., 1983. A short history of the Lunulite Bryozoa. Bulletin of the Marine Science, 33: 566-581.

Cook, P.L., Chimonides, P.J., 1984. Recent and fossil Lunulitidae (Bryozoa: Cheilostomata) 1. The genus Otionella from New Zealand. Journal of Natural History, 18: 227-254.

Cook, P.L., Chimonides, P.J., 1985a. Recent and fossil Lunulitidae (Bryozoa: Cheilostomata), 5. Selenaria alata Tenison Woods, and related species. Journal of the Natural History, 19: 337-358.

Cook, P.L., Chimonides, P.J., 1985b. Recent and fossil Lunulitidae (Bryozoa, Cheilostomata), 4. American and Australian species of Otionella. Journal of the Natural History, 19: 575-603.

Cook, P.L., Chimonides, P.J., 1986. Recent and fossil Lunulitidae (Bryozoa, Cheilostomata), 6. Lunulites sensu lato and the genus Lunularia from Australasia. Journal of the Natural History, 20: 681-705.

Crame, J.A., Beu, A.G., Ineson, J.R., Francis, J.E., Whittle, R.J., Bowman, V.C., 2014. The early origin of the Antarctic marine fauna and its evolutionary implications. PLOS one/ DOI:10.1371/journal.pone.0114743 
Dartevelle, E., 1932. Contribution a l'ètude des Bryozoaires fossils de l'Ėocène de la Belgique. Annales Societe Royale Zoologique de Belgique, 63: 55-116.

Del Valle, R.A., Elliot, D.H., MacDonald, D.I.M., 1992. Sedimentary basins on the east flank of the Antarctic Peninsula: proposed nomenclature. Antarctic Science, 4: 477-478.

Dingle, R.V., Lavelle, M., 1998. Antarctic Peninsular cryosphere: Early Oligocene (c. $30 \mathrm{Ma}$ ) initiation and a revised glacial chronology. Journal of the Geological Society, 155: 433-437.

Dutton, A.L., Lohmann, K., Zinsmeister, W.J., 2002. Stable isotope and minor element proxies for Eocene climate of Seymour Island, Antarctica. Paleoceanography, 17:1-13.

Dzik, J., Gaździcki, A., 2001. The Eocene expansion of nautilods to high latitudes. Palaeogeography, Palaeoclimatology, Palaeoecology, 172: 279-312

Elliot, D.H., 1988. Tectonic setting and evolution of the James Ross Basin, northern Antarctic Peninsula. GSA Memoir, 169: 541-555.

Elliot, D.H., Trautman, T.A., 1982. Lower Tertiary strata on Seymour Island, Antarctic Peninsula. In: Antarctic Geoscience (ed. C. Craddock): 287-297. The University of Wisconsin Press, Madison.

Feldmann, R.M., Wilson, M.T., 1988. Eocene decapod crustaceans from Antarctica. GSA Memoir, 169: 465-488.

Feldmann, R.M., Woodbourne, M.O., eds., 1988. Geology and Paleontology of Seymour Island, Antarctic Peninsula. GSA Memoir, 169: 1-566.

Gaździcki, A., 1996. Palaeontological results of the Polish Antarctic expeditions, Part II. Palaeontologia Polonica, 55: 1-192.

Gaździcki, A., 2001. Palaeontological results of the Polish Antarctic expeditions, Part III. Palaeontologia Polonica, 60: 1-184.

Gaździcki, A., Hara, U., 1994. Multilamellar bryozoans colonies in the Eocene La Meseta Formation of Seymour Island, Antarctica: a preliminary account. Studia Geologica Polonica, 104 105-116.

Gaździcki, A., Gruszczyński, M., Hoffman, A., Małkowski, K. Marenssi, S.A., Hałas, S., Tatur, A., 1992. Stable carbon and oxygen isotope record in the Paleogene La Meseta Formation, Seymour Island, Antarctica. Antarctic Science, 4: 461-466.

Gelfo, J.N., Mörs, T., Lorente, M., López, G.M., Reguero, M., 2015. The oldest mammals from Antarctica, early Eocene of La Meseta Formation, Seymour Island. Palaeontology, 58 $101-110$.

Gordon, D.P., 1984. The marine fauna of New Zealand: Bryozoa: Gymnolaenmata from the Karmadec Ridge. New Zealand Oceanographic Institute, Memoir, 91: 1-194.

Gordon, D.P., 1986. The marine fauna of New Zealand: Bryozoa: Gymnolaemata (Ctenostomata and Cheilostomata Anasca) from the western South Island continental shelf and slope. New Zealand Oceanographic Institute Memoir, 95: 1-121.

Gordon, D.P., 2014. Genera and subgenera of Cheilostomata. INTERIM Classification (Working Classsification for Treatise), http://www.bryozoa.net/treatfam.pdf

Gordon, D.P., Braga, G., 1994. Bryozoa: living and fossil species of the catenicellid subfamilies Ditaxiporinae Stach and Vasinyellidae nov. Memoire Museum du National d'Histoire Naturelle, 161: 55-85.

Gordon, D.P., Taylor, P.D., 1999. Latest Paleocene to earliest Eocene bryozoans from Chatham Island, New Zealand. Bulletin of the Natural History of London (Geological series), 55: 1-45.

Gordon, D.P., Taylor, P.D., 2015. Bryozoa of the Early Eocene Tumaio Limestones, Chatham Island, New Zealand. Journal of Systematic Palaeontology, 13: 983-1070.

Gregory, W., 1893. On the British Palaeogene. Transactions of the Zoological Society of London, 13: 219-279.

Greeley, R., 1969. Basally "uncalcified" zoaria of lunilitiform Bryozoa. Journal of Palaeontology, 43: 252-256.

Hageman, S.J., Bone, Y., McGowran, B., James, N.P., 1997. Bryozoan colonial growth-forms as paleoenvironmental indicators: evaluation of methodology. Palaios, 12: 405-419.

Håkansson, E., Voigt, E., 1996. New fee-living bryozoans from the northwest European Chalk. Bulletin of the Geological Society of Denmark, 42: 187-207.
Hara, U., 1997. Tertiary bryozoans of West Antarctica and their ecological and biogeographical implications. In: Polish Polar Studies, 24th Polar Symposium. Warszawa 1997 (ed. P. Głowacki): 115-140. Institute of Geophysics of the Polish Academy of Sciences, Warszawa.

Hara, U., 1998. Cenozoic bryozoans of the West Antarctic. Kosmos, 4: $431-438$.

Hara, U., 2001. Bryozoans from the Eocene of Seymour Island, Antarctic Peninsula. Palaeontologia Polonica, 60: 33-155.

Hara, U., 2002. A new macroporid bryozoan from Eocene of Seymour Island, Antarctic Peninsula. Polish Polar Research, 23: 213-225.

Hara, U., 2007. Biogeographical relationship of the South America-Antarctic Cenozoic bryozoans biota: the example of the austral genus Aspidostoma. In: Antarctica: a keystone in a changing world (eds. A.K. Cooper, C.R. Raymond and 10th ISEAS Editorial Team), 214. Online proceedings of the 10th ISEAS. USGS Open-File Report 2007-1047, Extended Abstract.

Hara, U., 2015. Bryozoan internal moulds from the La Meseta Formation (Eocene) of Seymour Island, Antarctic Peninsula. Polish Polar Research, 36: 25-49.

Hathway, B., 2000. Continental rift to back-arc basin: Jurassic-Cretaceous stratigraphical and structural evolution of the Larsen Basin, Antarctic Peninsula. Journal of the Geological Society, 157: 417-432.

Hinds, R.W. 1975. Growth mode and homeomorphism in cyclostomes Bryozoa. Journal of Palaeontology, 49: 875-910.

Ivany, L.C., Van Simaeys, S., Domack, E.W., Samson, S.D., 2006. Evidence for an earliest Oligocene ice sheet on the Antarctic Peninsula. Geology, 34: 377-380.

Ivany, L.C., Lohmann, K.C., Hasiuk, F., Blake, D.B., Glass, A. Aronson, R.B., Moody, R.M., 2008. Eocene climate record of a high southern latitude continental shelf: Seymour Island, Antarctica. GSA Bulletin, 120: 659-678.

James, N.P., 1997. The cool-water carbonate depositional realm. SEPM Special Publication, 56: 1-20.

Jerzmańska, A., Świdnicki, J., 1992. Gadiform remains from the La Meseta Formation (Eocene) of Seymour Island, West Antarctica. Polish Polar Research, 13: 241-253.

Kriwet, J., Gaździcki, A., 2003. New Eocene Antarctic chimeroid fish (Holocephali, Chimaeriformes). Polish Polar Research, 24 29-51

Lagaaij, R., 1952. The Pliocene Bryozoa of the Low Countries Mededelingen van de Geologische Stichting, serie C-V - No. 5: $1-185$.

Lagaaij, R., 1963. Cupuladria canariensis (Busk) - portrait of a bryozoans. Palaeontology, 6: 172-217.

Lagaaij, R., Cook, P.L., 1973. Some Tertiary to Recent Bryozoa. In: Atlas of Palaeobiogeography, (ed. A. Hallam): 489-498. Elsevier, Amsterdam

López-Cabrera, M.I., Olivero, E.B., 2011. An Eocene articulated Polyplacophora (Mollusca) from the La Meseta Formation, Antarctica and the stratigraphy of the fossil-bearing strata. Journal of Paleontology, 85: 970-976.

MacGillivray, P.H., 1895. A monograph of the Tertiary Polyzoa of Victoria. Transaction of the Royal Society of Victoria, new series, 4: 1-166.

Małecki, J., 1963. Bryozoa from the Eocene of the Central Carpathians between Grybów and Dukla (in Polish with English summary). Prace Geologiczne, 16: 1-158.

Maplestone, C.M., 1901. Further descriptions of the Tertiary Polyzoa of Victoria. Part VI. Proceedings of the Royal Society of Victoria, new series, 13: 204-213.

Maplestone, C.M., 1904. Tabulated list of the fossil cheilostomatous Polyzoa in the Victorian Tertiary deposits. Proceedings of the Royal Society of Victoria, 17: 182-219.

Marenssi, S.A., 2006. Eustatically controlled sedimentation recorded by Eocene strata of the James Ross Basin, Antarctica. Geological Society Special Publications, 258: 125-133.

Marenssi, S.A., Santillana, S.N., Rinaldi, C.A., 1998. Stratigraphy of the La Meseta Formation (Eocene) Marambio (Seymour) Island, Antarctica. Revista Asociaciòn Paleontològica Argentina, Publication Especial, 5: 137-146. 
Marenssi, S.A., Net, L.I., Santillana, S.N., 2002. Provenance, depositional and palaeogeographic controls on sandstone composition in an incised valley system: the Eocene La Meseta Formation, Seymour Island Antarctica. Sedimentary Geology, 150: 301-321.

McKinney, M.L., McNamara, K.J., Wiedman, L.A., 1988. Echinoids from the La Meseta Formation (Eocene), Seymour Island, Antarctica. GSA Memoir, 169: 499-503.

McKinney, F.K., Jackson, J.B.C., 1989. Bryozoan Evolution. Unwin Hyman, London.

McLoughlin, S., Bomfleur, B., Mörs, T., Reguero, M., 2016. Fossil clitellate annelid cocoons and their microbiological inclusions from the Eocene of Seymour Island, Antarctica. Palaeontologia Electronica, 19.1.11A: 1-27.

Milne-Edwards, H., 1836. Observations sur les polypiers fossils du genere Eschare. Annales des Sciences Naturalles. Zoologie (2e Serie), 6: 321-345.

Mozer, A., 2013. Eocene sedimentary facies in a volcanogenic succession on King George Island, South Shetland Islands: a record of pre-ice sheet terrestrial environments in West Antarctica. Geological Quarterly, 57 (3): 385-394.

Myrcha, A., Tatur, A., Del Valle, R., 1990. A new species of fossi penguin from Seymour Island (West Antarctica). Alcheringa, 14: 195-205.

O'Dea, A., 2009. Relation of form to life habit in free-living cupuladriid bryozoans. Aquatic Biology, 7: 1-18.

O'Dea, A., Herrera-Cubilla, A., Fortunato, H., Jackson, J.B.C., 2004. Life history variation in cupuladrid bryozoans from either side of the Isthmus of Panama. Marine Ecology Progress Series, 280: 145-161.

O'Dea, A., Jackson, J.B.C., Taylor, P.D., Rodriguez, F., 2008. Modes of reproduction in Recent and fossil cupuladriid bryozoans. Palaeontology, 51: 847-864.

O’Dea, A., Håkansson, E., Taylor, P.D., Okamura B., 2011. Environmental change prior to the K-T boundary inferred from temporal variation in the morphology of cheilostome bryozoans. Palaeogeography, Palaeoclimatology, Palaeoecology, 308: 502-512.

Ostrovsky, A.N., Taylor, P.D., 1996. Systematics of some Antarctic Idmidronea and Exidmonea (Bryozoa, Cyclostomata). Journal of Natural History, 30: 1549-1575.

Reguant, S., 1990. Metrarabdotos oriense n.sp. (Bryozoa Cheilostomata Ascophora) del Eoceno medio de Vic (BarceIona): una forma ramose singular. Revista Española de Paleontologia, 5: 71-76.

Reguero, M.A., Marenssi, S.A., Santillana, S.N., 2012. Weddellian marine/coastal vertebrates diversity from a basal horizon (Ypresian, Eocene) of the Cucullaea I Allomember, La Meseta Formation, Seymour (Marambio) Island, Antarctica. Revista Peruana de Biología, 19: 275-284.

Reguero, M., Goin, F., Acosta Hospitaleche, C., Dutra, T., Marenssi, S., 2013. Late Cretaceous/Palaeogene west Antarctica terrestrial biota and its intercontinental affinities. Springer Briefs in Earth System Sciences, London.

Rosso, A., 1996. Lunulitiform bryozoans and their autecology. Bolletino della Societa Palaeontologia Italiana. Spec. Vol., 3: 175-190.

Sadler, P., 1988. Geometry and stratification of uppermost Cretaceous and Paleogene units of Seymour Island, northern Antarctic Peninsula. GSA Memoir, 169: 303-320.

Schmidt, R., 2007. Australian Cenozoic Bryozoa, 2: Bonellina gen. nov. (Calloporidae, Cheilostomata), a new free-living bryozoans. Alcheringa, 31: 67-84.

Schmidt, R., Bone, Y., 2001. Eocene bryozoan assemblages of the St. Vincent Basin, South Australia. In: Bryozoan Studies 2001 (eds. P. Wyse Jackson, C. Buttler and M. Spencer Jones): 293-298. A.A. Balkema Publishers, Lisse.

Schmidt, R., Bone, Y., 2003. Biogeography of Eocene bryozoans from St. Vincent Basin, South Australia. Lethaia, 36: 287-382.

Schwarzhans, W., Mörs, T., Engelbrecht, A., Reguero, M., Kriwet, J., 2016. Before the freeze: Otoliths from the Eocene of
Seymour Island, Antarctica, reveal dominance of gadiform fishes (Teleostei). Journal of Systematic Palaeontology, 15: 147-170; doi: 10.1080/14772019.2016.1151958

Smith, A.M., 1995. Palaeonvironmental interpretation using bryozoans: a review. Geological Society Special Publications, 83: 235-243.

Smith, A.M., Nelson, C.S., 1993. Mineralogical, carbonate geochemical and diagenetic data for modern New Zealand bryozoans. Occasional Report, 17. Department of Earth Sciences, University of Waikato, Hamilton New Zealand.

Smith, A.M., Nelson, C.S., Spencer, H.G., 1998. Skeletal mineralogy of New Zealand bryozoans. Marine Geology, 151: 27-46.

Smith, A.M., Key, M.M. Jr., Gordon, D.P., 2006. Skeletal mineralogy of bryozoans: Taxonomic and temporal patterns. Earth-Science Reviews, 78: 287-306.

Stach, L.W., 1936. Correlation of zoarial form with habitat. Journal of Geology, 44: 60-65.

Steger, K.K., Smith, A.M., 2005. Carbonate mineralogy of free-living bryozoans (Bryozoa: Otionellidae), Otago shelf, southern New Zealand. Palaoegeography, Palaeoclimatology, Palaeoecology, 218: 195-215.

Stilwell, J.D., Zinsmeister, W.J., 1992. Molluscan systematic and biostratigraphy. Lower Tertiary La Meseta Formation, Seymour Island, Antarctic Peninsula. Antarctic Research Series, 55: $1-192$.

Tatur, A., Krajewski, K.P., Valle, R.A. del, 2011. The facies and biota of the oldest expose strata of the Eocene La Meseta Formation (Seymour Island, Antarctica). Geological Quarterly, $\mathbf{5 5}$ (4): 345-360.

Taylor, P.D., Gordon, D.P., 2003. Endemic new cyclostome bryozoans from Spirits Bay, a New Zealand marine-biodiversity "hotspot". New Zealand Journal of marine and Freshwater Research, 37: 653-669.

Taylor, P.D., James, N.P., 2013. Secular changes in colony-forms and bryozoans carbonate sediments through geological history. Sedimentology, 60: 1184-1212.

Taylor, P.D., McKinney, F.K., 2006. Cretaceous Bryozoa from the Campanian and Mastrichtian of the Atlantic and Coastal Plains, United States. Scripta Geologica, 26: 459-462.

Taylor, P.D., Kudryavtsev, A.B., Schopf, J.W., 2008a. Calcite and aragonite distributions in the skeletons of bimineralic bryozoans as revealed by Raman spectroscopy. Invertebrate Biology, 127: 87-97.

Taylor, P.D., Casadío, S., Rosa, S., Gordon, D.P., 2008b. A rare form of frontal shield development in a new cheilostome bryozoans genus Uharella from the Eocene of Antarctica. Paläontologische Zeitschrift, 82: 262-268.

Taylor, P.D., James, N.J., Bone, Y., Kukliński, P., 2009. Evolving mineralogy of Cheilostome bryozoans. Palaios, 24: 440-452.

Uttley, G.H., 1949. The Recent and Tertiary Polyzoa (Bryozoa) in the collection of the Canterbury Museum, Christchurch. Records of the Canterbury Museum, 5: 167-192.

Waters, A., 1884. Fossil Cyclostomatous Bryozoa from Australia. Quarterly Journal of the Geological Society, 40: 674-696.

Waters, A., 1887. On Tertiary Cyclostomatous Bryozoa from New Zealand. Quarterly Journal of the Geological Society, 43: 337-350.

Zinsmeister, W.J., 1991. Review of the biogeographical history of Seymour Island molluscan faunas: a look at climate changes in the high southern latitudes during the Late Cretaceous and Early Tertiary. International Conference on the Role of the Southern Ocean and Antarctica in Global Change: an Ocean Drilling Perspective, University of California, Santa Barbara, California, Abstracts, 70.

Zinsmeister, W.J., Feldmann, R.M., 1984. Cenozoic high latitude heterochronity of Southern Hemisphere marine faunas. Science, 224: 281-283.

Zullo, V.A., Feldmann, R.M., Wiedman, L.A., 1988. Balanomorph Cirripedia from the Eocene La Meseta Formation, Seymour Island, Antarctica. GSA Memoir, 169: 459-464. 